Ryszard Małachowski ${ }^{1}$

Uniwersytet Zielonogórski

\title{
AKSJOLOGIA WYCHOWANIA CHRZEŚCIJAŃSKIEGO DO MIŁOŚCI - MAŁŻEŃSTWA - RODZINY W KAZNODZIEJSTWIE I PEDAGOGII KS. JULIANA MICHALCA (1922-1988)
}

The Axiology of Christian Education for Love, Marriage and Family in the Preaching and Pedagogy of Father Julian Michalec (1922-1988)

Summary: The article examines axiological Christian education in the preaching and pedagogy of Father Julian Michalec, who was born in the South-Eastern Borderlands of the Second Polish Republic in 1922 and who died in 1988. The teaching of this priest-educator was aimed mainly at the academic youth of the Przemyśl and Wrocław Archdioceses in the period 19621988, during the time of the Polish People's Republic. The teaching took place in totalitarian conditions, especially as regards education for love, marriage and family (axiological context: religious and educational; selected aspects of religion, cultural studies, history, and, in particular, family sciences, related to philosophy and theology, anthropology, ontology, axiology and pedagogy as well as psychology and sociology) and it prevented the Polish youth and their families from being dechristianised.

Keywords: biography, value, axiology, sermon, homily, love, marriage, family, priest-educator, Catholic ministry for students, Christianity

1 Dr Ryszard Małachowski - pracownik naukowo-dydaktyczny Wydziału Pedagogiki, Psychologii i Socjologii Uniwersytetu Zielonogórskiego. Adres: al. Wojska Polskiego 69, 65-762 Zielona Góra; e-mail: r.malachowski@ipp.uz.zgora.pl. 


\section{Wstęp}

$\mathrm{Z}$ wydanej drukiem podstawy biograficznej niniejszego artykułu autorstwa ks. Krzysztofa Moszumańskiego wynika, że ks. Julian Michalec ${ }^{2}$ urodził się w II Rzeczypospolitej Polskiej na Kresach Południowo-Wschodnich ${ }^{3}$, w województwie lwowskim 3 czerwca 1922 roku we wsi Binarowa, w małżeństwie sakramentalnym, w religijnej i patriotycznej rodzinie. Ochrzczony w Kościele rzymskokatolickim w dniu 5 czerwca 1922 roku, wychowywany w miejscu urodzenia, ukończył cykl nauki w Szkole Podstawowej w 1933 roku. Został absolwentem rzeszowskiego Gimnazjum (w 1938 roku) oraz w czasie wojny przemyskiego Gimnazjum i Liceum („Niższego Seminarium Duchownego”), uzyskując maturę 1 lipca 1941 roku w Sandomierzu. Po wojnie, w 1945 roku, wstąpił do Wyższego Seminarium Duchownego obrządku łacińskiego w Przemyślu, po ukończeniu którego przyjął w katedrze przemyskiej święcenia kapłańskie oraz zleconą mu misję. Obroniwszy pracę magisterską 27 czerwca 1951 roku, uzyskał stopień doktora 28 czerwca 1952 roku, zostając w macierzystej diecezji wikariuszem i katechetą w parafii pw. św. Stanisława w Łańcucie. Sława „wybitnego kaznodziei”, „przewodnika duchowego młodzieży", korzystny wpływ duszpastersko-wychowawczy stały się przyczyną ataków władz ludowych, a w konsekwencji ekskardynacji księdza z jednostki terytorialnej, jaką stanowiła archidiecezja przemyska. Po inkorporowaniu do archidiecezji wrocławskiej w 1962 roku, kontynuując obowiązki kapłańskie, kaznodziejskie, dydaktyczne we Wrocławiu, wkrótce i tam okazał się niezrównanym w opinii społecznej wzorem młodzieży świeckiej i kleryckiej. Pomimo wyczerpującej aktywności, pogarszającego się stanu zdrowia, zwolnienia z wykładów w Wyższym Seminarium Duchownym, funkcji proboszcza (w 1983 roku), zagrożenia życia (poważne symptomy kardiologiczne) ks. Michalec nie porzucił

2 Krzysztof Moszumański, Ks. Julian Michalec (1922-1988). Człowiek i dzieło (Świdnica: Świdnicka Kuria Biskupia 2005), 6.

3 W II RP „Kresy Wschodnie były zamieszkane przez szlachtę polską, zaś «Kresy Zachodnie» przez lud polski. [...]. Z tego też powodu uzasadnione wydaje się wprowadzenie już na przełomie XIX i XX wieku rozróżnienia między obydwoma obszarami, także nazewniczego: na kresy i pogranicze. Przez pogranicze rozumiano obszary zachodnie, niejednolite narodowościowo, historycznie polskie w okresie przed rozbiorami, później podporządkowane państwu pruskiemu (niemieckiemu) i co istotne na tych obszarach strona polska była w defensywie. «W odróżnieniu od Kresów - pisał W. Wrzesiński - pogranicze było przedmiotem wpływów, ale i wzajemnego przenikania zjawisk kulturowych wykształconych przez oba narody». Z czasem jednak - wobec wzrastającej germanizacji, przewaga Niemców okazała się tak przytłaczająca, że owe wzajemne relacje i wpływy stawały się coraz bardziej jednostronne. Inaczej było na Kresach, gdzie «przejmowanie wzorów polskich», polskiej kultury obserwujemy jeszcze przez cały wiek XIX”. Zbigniew Fras, „Kresy i pogranicza”, w: Kresy i pogranicza, Historia, kultura, obyczaje, red. Zbigniew Fras, Andrzej Staniszewski (Olsztyn: Wydawnictwo Wyższej Szkoły Pedagogicznej 1995), 10; Henryka Ilgiewicz, „Litewska kontestacja pojęcia „Kresy Wschodnie”, w: Europa nie prowincjonalna. Przemiany na ziemiach wschodnich dawnej Rzeczypospolitej (Białoruś, Litwa, Łotwa, Ukraina, wschodnie pogranicze III Rzeczypospolitej Polskiej) w latach 1772-1999, red. Krzysztof Jasiewicz (Warszawa: Oficyna Wydawnicza Rytm 1999), 124. 
misji kaznodziejsko-pedagogicznej. Zmarł we Wrocławiu (w 1988 roku), w chwili gdy wielka martyrologia wiernych i kapłanów Kościoła katolickiego rozpoczęta w Polsce Ludowej, kontynuowana w Polskiej Rzeczypospolitej Ludowej (faktycznie od 1944 roku, oficjalnie od 1952 do 1989 roku) dochodziła kresu, ale nie kończyła się definitywnie. Wymieniona okoliczność poznawcza sprzyjała podjęciu aktywności naukowej, związanej z „kresowymi” biografiami wyznaczonego obszaru aksjologicznego, tj. z „kresową” biografią ks. J. Michalca.

\section{Stan badań, problematyka i cel pracy oraz inne zagadnienia metodologiczne}

Po wiekach dominacji „heroicznego” w historii i kulturze biograficznego podmiotu indywidualnego przyszedł czas na „portrety” wybitnych kreatorów wartości zamieszczone m.in. w „polskiej biografii naukowej” w 1922 roku, do czego wzywał Władysław Konopczyński. O uzasadnionej konieczności rekonstrukcji „pełnej biografii polskiej” w 1929 roku pisał Stanisław Kot ${ }^{4}$. W 1993 roku po raz pierwszy wydano książkę Wincentego Okonia pt. Wizerunki sławnych pedagogów polskich. Z początkiem XXI wieku ukazało się dzieło Czesława Kupisiewicza napisane we współautorstwie z Małgorzatą Kupisiewicz Poczet wybitnych nauczycieli ${ }^{5}$. Oprócz klasyków zbiorowej formy biograficznej z przeszłości ${ }^{6}$ współczesność zapoznaje pokolenia twórców, historyków, socjologów, coraz częściej psychologów (definicja i wyznaczniki portretu psychologicznego ${ }^{7}$ ), pedagogów-biografistów, historyków wychowania, przedstawiających życiorysowe portrety indywidualne, podobizny nie zbiorowe. Wśród pedagogów Agnieszka Wałęga ${ }^{8}$ wskazuje na dokonania Eleonory Sapii-Drewniak (biografia pedagogiczna Stefanii Mazurek ${ }^{9}$ ), Władysławy Szulakiewicz (biografie uczonego Ludwika Chmaja). Wymienia się osiągnięcia Dominiki Jagielskiej, Janiny Kostkiewicz (twórczyni książki bio-

4 Władysława Szulakiewicz, „Andragogiki portret zbiorowy w kontekście dyskusji o sensie badań biograficznych”. Rocznik Andragogiczny 20 (2013): 256.

5 Czesław Kupisiewicz, Małgorzata Kupisiewicz, Poczet wybitnych nauczycieli (Pułtusk: Wydawnictwo Akademia Humanistyczna im. A. Gieysztora w Pułtusku cz. I (2006), cz. II (2007)).

6 William L. Thomas, Florian Znaniecki, Chłop polski w Europie i Ameryce, przeł. Anna Bartkowicz (Warszawa: Ludowa Spółdzielnia Wydawnicza 1976); Józef Chałasiński, Młode pokolenie wsi Polski Ludowej. Awans pokolenia. Pamiętniki i Studia, t. 1 (Warszawa: Ludowa Spółdzielnia Wydawnicza 1964).

7 Biograficzne badania nad twórczością. Teoria i empiria, red. Monika Modrzejewska-Świegulska (Łódź: Wydawnictwo Uniwersytetu Łódzkiego 2016), 36-37.

8 Agnieszka Wałęga, „Biografistyka w naukach o wychowaniu na marginesie pracy Stefania Mazurek. Biografia pedagogiczna”. Pedagogika 38 (2012).

9 Bohaterka biografii pedagogicznej (monografii), była pedagogiem-andragogiem młodzieży i dorosłych, patriotką, działaczką oświatową, aktywną po II wojnie światowej w dziele repolonizacji Śląska. Eleonora Sapia-Drewniak, Stefania Mazurek. Biografia pedagogiczna (Opole: Wydawnictwo Uniwersytetu Opolskiego 2011). 
graficznej o pedagogu-żołnierzu Andrzeju Niesiołowskim ${ }^{10}$ ), Wiesława Theissa (autora biografii ks. Henryka Szumana przedstawionego jako społecznika ${ }^{11}$ ). Pozostające $\mathrm{z}$ reguły na peryferiach piśmiennictwa życiorysowego biografie kapłanów, szczególnie kresowych, wpisują się w wielowiekowe niezastąpione i wartościowe dzieło organicznej misji osób, instytucji katolickich, na których zaangażowanie wskazuje Piotr Mazur ${ }^{12}$. Podobnie o. Jacek Woroniecki stwierdza, iż religijnemu systemowi pedagogicznemu skutecznie służą księża i inne osoby duchowne (zakonne) wraz z wyspecjalizowanym aparatem wychowawczym Kościoła, „z całym jego nadprzyrodzonym życiem, nauką, liturgią, sakramentami i duszpasterstwem"13.

$\mathrm{Z}$ powyższym stanowiskiem oraz przedmiotem moich rozważań (aksjologiczne wychowanie katolickie) koreluje inicjatywa badawcza Janiny Kostkiewicz i jej dojrzała autorska rekonstrukcja pedagogii zgromadzeń zakonnych (zbiór koncepcji teoretycznych, zagadnień praktycznych, opiekuńczych $\mathrm{w}$ obszarze wychowania katolickiego), wywodzących się z systemu pedagogiki chrześcijańskiej ${ }^{14}$. Adekwatnie wykorzystując zastosowane w niej elementy, pominąłem w opisie postaci materiały archiwalne (instytucjonalne, tzn. oficjalne, prywatne - osobiste) użyte w publikacji Krzysztofa Moszumańskiego pt. Ks. Julian Michalec (1922-1988), Człowiek $i$ dzieło ${ }^{15}$. W wyczerpującym stopniu spełniły swoje zadanie w pierwszym $\mathrm{z}$ moich artykułów o tym kapłanie ${ }^{16}$, stanowiącym obszerne wprowadzenie biograficzne. Natomiast niniejszy artykuł oparty został przede wszystkim na wcześniej wydanej reprezentatywnej podstawie, zawierającej oryginalny zbiór kazań kresowego kapłana pt. Ks. Julian Michalec. Aby życie mieli $^{17}$. Są to najważniejsze teksty legitymizujące religijne przesłanie pedagogii życia, ujmowane $\mathrm{w}$ aksjologicznym wymiarze duszpastersko-wychowawczym,

10 Dominika Jagielska, Janina Kostkiewicz, Pedagogika humanizmu społecznego Andrzeja Niesiołowskiego (Kraków: Wydawnictwo Uniwersytetu Jagiellońskiego 2015).

11 Wiesław Theiss, Troska i nadzieja: działalność społeczno-wychowawcza ks. Henryka Szumana na Pomorzu w latach 1908-1939, wyd. 1 (Toruń: Wydawnictwo Adam Marszałek 2012).

12 Piotr Mazur, Podstawy pedagogiki pastoralnej (Kraków: Wydawnictwo Apostolstwa Modlitwy 2011), 11 i inne.

${ }_{13}$ Jacek Woroniecki, „Program pedagogiki katolickiej”, w: Pedagogika katolicka, Zagadnienia wybrane, red. Alina Rynio (Stalowa Wola: Oficyna Wydawnicza Fundacji w Stalowej Woli 1999), 16.

14 Pedagogie katolickich zgromadzeń zakonnych. Historia i wspótczesność, t. 1, red. Janina Kostkiewicz (Kraków: Oficyna Wydawnicza „Impuls” 2012), 7-8.

15 Moszumański, Ks. Julian Michalec.

16 Ryszard Małachowski, „Nauczanie duszpastersko-wychowawcze w biografii pedagogicznej oraz kazaniach księdza Juliana Michalca (XX wiek)", Scientific Bulletin of Chełm, Section of Pedagogy 1 (2017).

17 Ks. Julian Michalec, Aby życie mieli. Wybór kazań, t. 1, wyb. i red. Maria Lubieniecka (Kraków: Wydawnictwo OO. Franciszkanów Bratni Zew 2001), 13; Ks. Julian Michalec, Aby życie mieli. Wybór kazań, t. 2, wyb. i red. Maria Lubieniecka (Kraków: Wydawnictwo OO. Franciszkanów Bratni Zew 2002). 
sakramentalno-wspólnotowym (miłość - małżeństwo - rodzina) ${ }^{18}$. Poza tym opracowaniem istniejące, niedostępne maszynopisy kazań ks. J. Michalca znajdują się niemal wyłącznie w prywatnych archiwach ${ }^{19}$, a ich zebranie w przewidywalnym czasie jest obecnie niemożliwe. Ważkie poznawczo okazały się źródłowe ustalenia biograficzne K. Moszumańskiego, wskazujące na ks. J. Michalca w zaledwie kilku stronicowych opracowaniach biograficznych księży: Józefa Patera, Zbigniewa Bielamowicza, biskupa Ignacego Deca, wspomnieniach i szkicach innych osób ${ }^{20}$.

Problematykę, cel, uwarunkowania i granice badań określające zakres niewiedzy, wyznaczyły następujące pytania: na jakie wartości zwracał uwagę ks. J. Michalec w swym chrześcijańskim nauczaniu, kaznodziejstwie i pedagogii i czy pomagały one rodzinie katolickiej XX wieku w osiąganiu maksymalnego poziomu realizacji zadań małżeńskich, rodzinnych, społecznych i eschatologicznych. Problemem wyjściowym stała się trudność, pytanie o naturę badanego zjawiska, jego istotę i cechy procesów w nim zachodzących. Pomimo iż problematyka ta okazała się dostępna badawczo we wspomnianej publikacji K. Moszumańskiego ${ }^{21}$, również ona przedstawiona została $\mathrm{w}$ minimalnym zakresie (zgodnie z przyjętą procedurą autorską). $\mathrm{Z}$ tego powodu podstawą moich badań okazała się obszerna dwuczęściowa publikacja zatytułowana Ks. Julian Michalec. Aby życie mieli²2, zawierająca bardziej rozbudowaną tematykę aksjologicznych podstaw miłości małżeństwa - rodziny. Dla odkrycia tego, jakie wartości ks. J. Michalec chciał przedstawić i na czym polega ich oryginalność, wybrałem metodę studium aksjologiczno-pedagogicznego (siedmioczęściowego ze wstępem i zakończeniem) wraz z techniką analizy jakościowej kazań i homilii (u innych jest to metoda).

18 Posługa kapłańska to jednocześnie posługa wychowawcy. Jan Niewęgłowski, Wychowawczo-społeczna działalność salezjanów w Polsce w latach 1898-1989 (Warszawa: Towarzystwo Naukowe Franciszka Salezego 2011), 96.

19 Na temat życia i działalności ks. Michalca brak szerszych opracowań. Ukazały się jedynie krótkie biogramy. Jedynym opracowaniem naukowym na temat kaznodziejstwa ks. Michalca pozostaje praca magisterska napisana przez ks. Mariusza Skibę. Niezwykle cenne okazały się wspomnienia ks. Juliana Michalca spisane przez Marię Lubieniecką w latach 2000-2003. Zbiór kazań ks. J. Michalca w postaci maszynopisów mów, jest w posiadaniu ks. Bielamowicza (ale niestety nie można z niego skorzystać) oraz w klasztorze Sióstr Benedyktynek w Żarnowcu na Pomorzu. Wśród drukowanych źródeł do badań kaznodziejstwa ks. Michalca należy wymienić przede wszystkim wydany dwukrotnie po jego śmierci zbiór kazań: Aby życie mieli. Moszumański, Ks. Julian Michalec, 12-15.

20 Michalec, Aby życie mieli, t. 1, 13; t. 2, 278.

21 Moszumański, Ks. Julian Michalec, 231-233.

22 Michalec, Aby życie mieli, t. 1, 13; t. 2. 


\section{Aksjologiczne inspiracje w chrześcijańskim wychowaniu do miłości - małżeństwa - rodziny w pedagogii ks. Michalca}

Tymczasem dla rozważań znajdujących się w obszarze subdyscypliny aksjologiczno-pedagogicznej w zakresie wychowania kluczowym terminem jest potocznie rozumiane słowo wartość oznaczające coś cennego, godnego poszukiwań, wartościowego (áksios) pod różnym względem. Pierwsza z opracowanych przeze mnie publikacji, pt. Nauczanie duszpastersko-wychowawcze w biografii pedagogicznej oraz kazaniach księdza Juliana Michalca (XX wiek), ujmowała całość problematyki zawartej w jego nauczaniu (t. 1 i $2^{23}$ ), przedstawionej na tle biografii kompletnej (XX wiek) ${ }^{24}$. Drugi artykuł, pt. Aksjologia wychowania do miłości - małżeństwa - rodziny w kaznodziejstwie i pedagogii księdza Juliana Michalca $(X X$ w.), stanowi dopełnienie pierwszego poprzez wyodrębnienie $\mathrm{z}$ jego treści aksjologiczno-wychowawczych zagadnień miłości - małżeństwa - rodziny. Główny zakres aksjologii ks. J. Michalca wyjaśniany jest w perspektywie „wartości chrześcijańskich” XX wieku ${ }^{25}$. W filozofii klasycznej wartość oznacza wspomniane dobro, które w wymiarze transcendentalnym wywołuje: miłość, prawdę, piękno, świętość (transcendentalia). Rozważania o nich zapoczątkowały powstanie teorii wartości (Eduard von Hartmann) i aksjologii (L. Papie prekursor pojęcia, ale tylko w odniesieniu do nauki o wartościach; w szerszym znaczeniu jako pierwszy zastosował je Hartmann). W naukowym języku filozofii określenie „wartość" użyto pod koniec XIX wieku w idealizmie niemieckim (Immanuel Kant, Friedrich W. Nietzsche). Aksjologia jako nauka jest więc dyscypliną młodą, przy czym do jej rozwoju najbardziej przyczyniła się fenomenologia: Franza Brentany, Maxa Schelera, Roberta Ingardena. W procesie tym różne racje i stanowiska wywołały podziały na aksjologie naukowe, humanistyczne, nawiązujące do ideologii społecznych (konserwatywnych, liberalnych). Zaistniały wówczas nietrwałe aksjologie mieszane, a w nurtach pokantowskich (od pragmatyzmu do egzystencjalizmu) tworzono różne jej postaci i hierarchie. Niemniej aksjologia pozostała nauką o wartościach badającą obiektywny czy subiektywny sposób ich istnienia, poznanie wartości, ich liczbę, klasyfikację, hierarchizację, zależność (subiektywizm aksjologiczny) lub niezależność od podmiotu (obiektywizm), autonomię od innych rzeczy (relatywizm), całkowitą niezależność (absolutyzm).

23 Tamże.

24 Obszerniejsze dane biograficzne podaję za: Małachowski, Nauczanie duszpastersko-wychowawcze, 173-177. W niepomiernie większym stopniu biogram ks. J. Michalca opracowano w: Moszumański, Ks. Julian Michalec, 19-69.

25 „Wartości”, w: Stanisław Kowalczyk, Z refleksji nad człowiekiem. Człowiek - społeczność wartość (Lublin: Towarzystwo Naukowe Katolickiego Uniwersytetu Lubelskiego 1995), 215-224. 
Aksjologia poszukuje źródeł wiedzy o wartościach, którymi dla człowieka jest potoczne doświadczenie, intuicja, zmysł moralny, „Objawienie Boże” (w Piśmie Świętym) i w tymże chrześcijańskim-religijnym sensie stanowi podstawę dociekań aksjologicznych w niniejszym studium. Ks. J. Michalec ukazuje w nim integralnie pojmowane kaznodziejstwo łączone $\mathrm{z}$ pedagogią, $\mathrm{tj}$. aksjologicznym wychowaniem chrześcijańskim ${ }^{26}$ : do personalistycznych wartości poznawczo-intelektualnych, estetycznych, moralnych, społeczno-narodowych, religijnych ${ }^{27}$. W istotnym stopniu koncentruje się na indywidualnym „przeżywaniu” (kategoria przez niego stosowana), moralno-etycznej i społecznej ocenie realizacji moralnych wartości chrześcijańskich, w najpełniejszym sensie „osobowych”28. Wprowadza w teoretyczne i praktyczne aspekty namysłu i działalności katolickiego duszpasterza-wychowawcy. Rekonstruuje bytowe „doświadczenia” (pojęcie dobrze skategoryzowane $\mathrm{w}$ teologii, filozofii, psychologii ${ }^{29}$ ) księdza, jego czyn i dzieło. Wymienia istotne dla rozwoju osobowego wartości „socjalizujące”: rodzinę, szkoły, instytucje kościelne. Doświadczenia te implementowane w reflektowanej później praktyce duszpastersko-wychowawczej, wspomagały ogląd dostępnej mu chrześcijańskiej aksjosfery, tj. ówczesnej rzeczywistości aksjologicznej, dostrzeżonych treści problemowych. Wskazywały na integralny i komplementarny charakter natury mężczyzny, kobiety, macierzyństwa, ojcostwa, ich zależności, dopełniające różnice, funkcje, zadania. Wymienione elementy wpisywał w zakres precyzyjnie określonych chrześcijańskich wymagań oraz problemów wychowania do małżeństwa i rodziny ${ }^{30}$ (kontekst religijno-wychowawczy, wybrane aspekty filozoficzno-teologiczne, antropologiczne, ontologiczne, aksjologiczno-pedagogiczne, psychologiczne i socjologiczne: religii, kulturoznawstwa, historii, zwłaszcza nauk o rodzinie).

W opracowanych redakcyjnie materiałach źródłowych ${ }^{31}$ nie odnalazłem systematycznie opracowywanego przez ks. J. Michalca specyficznie autorskiego systemu aksjologicznego, poza wynikającym z jego nauczania integralnym systemem chrześcijańskim. Jednakże nawet gdyby istniało takie opracowanie, znacznie przekraczałoby zakres podjętych $\mathrm{w}$ artykule badań. Nie odnalazłem także innego niż chrześcijański modelu pedagogii miłości - małżeństwa - rodziny ks. J. Michalca. Wyodrębniłem zatem rzetelnie (unikając ryzyka nadinterpretacji) chrześcijańską sumę wartościujących oryginalnych przemyśleń

26 Gravissimum educationis. Deklaracja o wychowaniu chrześcijańskim (Sobór Watykański II), Przedruk za Sobór Watykański II, Konstytucje, dekrety, deklaracje (Poznań: Wydawnictwo Oficyna Współczesna 2001).

27 Stanisław Kowalczyk, Człowiek w poszukiwaniu wartości, Elementy aksjologii personalistycznej (Lublin: Wydawnictwo KUL 2006), 168-190.

28 Katarzyna Olbrycht, Prawda, dobro, piękno w wychowaniu człowieka jako osoby (Katowice: Wydawnictwo Uniwersytetu Śląskiego 2000), 179.

29 Jadwiga Szymaniak, „Metoda biograficzna w pedagogice”, Studia Gdańskie 10 (2013), 374.

30 Problemy małżeństwa i rodziny, w: Michalec, Aby życie mieli, t. 2, 137-173.

31 Michalec, Aby życie mieli, t. 1, 13; t. 2. 
prorodzinnych, skierowanych przez wybitnego znawcę przedmiotu, jakim był dla ogółu słuchaczy, młodzieży akademickiej, świeckiej i kleryckiej. Czynił to poprzez swe nauczanie: kazania, homilie, katechezy, konferencje okolicznościowe (np. rekolekcje, „Tygodnie Kultury Chrześcijańskiej”). Dostrzeżone tam elementy osobotwórcze immanentnie związane $\mathrm{z}$ paideią, $\mathrm{tj}$. ideą wychowawczą, ideałem wychowania J. Michalca, zmierzały za Stanisławem Nalaskowskim do pytań rozstrzygnięcia: kim jest człowiek, jaki jest i będzie jego świat w przyszłości, sens jego życia ${ }^{32}$. W komplementarnym znaczeniu dopełniała je troska o to, czy człowiek współczesny i człowiek przyszłości odkryje, pogłębi rozumienie istoty człowieczeństwa, dążąc do ukształtowania jego pełni (greckie rozumienie paidei jako idei wychowawczej) ${ }^{33} \mathrm{w}$ pedagogicznej perspektywie chrystologiczno-zbawczej. Z tak określonej perspektywy oprócz paidei do kluczowych terminów nauczanie, pedagogia (i ich rodzajów) ${ }^{34}$ nawiązuje wielu wybitnych pedagogów. J. Kostkiewicz sugeruje, iż pedagogia jako dzieło wychowania stanowi zespół czynności, umiejętności nauczyciela-wychowawcy (paidagogosa) skoncentrowanego na opiece fizycznej, kształceniu umysłowym, prowadzeniu duchowo-moralnym, tj. czynnościach tożsamych $\mathrm{z}$ wychowaniem, wiedzą o technikach wychowania $^{35}$. W obszarze pedagogiki religijnej (badania nad pedagogiami zgromadzeń zakonnych) przyjmuje za Zbigniewem Kwiecińskim najszersze rozumienie słowa pedagogia. Zdaniem autorki pedagogie zgromadzeń zakonnych, $\mathrm{z}$ jednej strony wpisują się w historię wychowania, a mając jednak niepowtarzalny charakter wykraczają poza współczesne badania teoretyczno-naukowe, kierując się inspiracją ewangeliczną w rozwiązywaniu problemów teorii i praktyki wychowawczej ${ }^{36}$.

32 Olbrycht, Prawda, 20-21.

33 Tamże, 16.

34 Pedagogie katolickich zgromadzeń, 7-8. P. Mazur, powołując się na Stefana Kunowskiego, przypomina, że ten wyodrębnia dwa podstawowe określenia: pedagogika i pedagogia (formowanie umysłowe, moralne). Pedagogia „oznacza samo dzieło wychowywania, zespół czynności i umiejętności wychowawczych, np. pedagogia domowa, szkolna, kościoła” (Mazur, Podstawy pedagogiki pastoralnej, 27).

35 Dla Stefana Kunowskiego pedagogia to formowanie umysłowe, moralne człowieka, wychowywanie wraz z zespołem czynności i umiejętności wychowawczych. J. Kostkiewicz wskazuje na jej ujęcia u Bogusława Milerskiego, Bogusława Śliwerskiego przypominając, iż pedagogia to „sztuka wychowania”, swoisty „paradygmat edukacyjny” mogący przybrać formę doktryny pedagogicznej, ideologii edukacyjnej, ukrytego programu wychowawczego. Pedagogie katolickich zgromadzeń, 18. Teresa Hejnicka-Bezwińska powołuje się na definicję pedagogii jako „paradygmatu edukacyjnego" autorstwa Zbigniewa Kwiecińskiego. Jest on: charakterystycznym dla danego kręgu kulturowego sposobem rozumienia istotnych funkcji oświaty, filozofii społecznej, przekonań politycznych, ideologii, epistemologii (metody epistemicznej, źródła, funkcji i sposobu dystrybucji wiedzy), teorii psychologicznej (analizy faktów psychologicznych), teorii socjologicznej (społeczeństwa i podmiotów edukacyjnych), celów, treści, środków dotyczących edukacji oraz właściwej sobie strategii wobec zachodzących zmian (taż, „Problemy aksjologiczności pedagogii”, w: Pedagogika ogólna. Problemy aksjologiczne, red. Teresa Kukołowicz, Marian Nowak (Lublin: Redakcja Wydawnictw KUL 1997), 167).

36 Pedagogie katolickich zgromadzeń, 18-19. 
Co do genezy „wartości” również one są jednym z najdonioślejszych kulturowo przedmiotów intuicji poznawczej, refleksji potocznej, rygorystycznej myśli naukowej i innych dokonań cywilizacyjnych człowieka. Będąc wychowawczym fenomenem, uniwersum antroposferycznego różnych epok, odpowiednio do użytej dyscypliny mają zróżnicowany charakter ${ }^{37}$, także aksjologiczno-pedagogiczny (subdyscyplina wywiedziona $\mathrm{z}$ pedagogiki ogólnej i aksjologii ${ }^{38}$ ). Podejmując sens aksjologiczny wychowania wspieranego interdyscyplinarnie rozwijającymi się dziedzinami i dyscyplinami, ze względu na rozwój aksjologii pedagogiki ${ }^{39}$, nie zgłaszam pretensji do pełnego definiowania tejże subdyscypliny. Poza elementarnymi wyjaśnieniami koniecznymi z punktu widzenia niniejszego opracowania tożsame stanowisko ograniczające zajmuję wobec dylematu wyjaśniania terminu „wartość”, ponieważ „od dawna” ${ }^{40}$ czyniła to najstarsza, najobszerniejsza z dziedzin ludzkiego poznania, filozofia, jako „mądrość” wieńcząca doświadczenie życia i nauk ${ }^{41}$. Po niej czyniły swą powinność wymienione już dyscypliny. Ze względu na współczesne rozumienie wartości, głównie teocentryczny i teologiczny zakres ich stosowalności przez ks. J. Michalca, wskazuję tym razem, chociaż także kontekstualne i dopełniające temat rozważań ogólne znaczenie ich definicji, wyznaczanych przez Marię Misztal ${ }^{42}$. U tej autorki mają one charakter psychologiczny, socjologiczny i kulturowy, z których dla aktywizowania psyche (psychiki rozumnej duszy), wychowania, samowychowania, adekwatna okazuje się psychologiczna definicja Carla Gustava Younga. W jego przekonaniu „wartość” okazuje się związkiem idei oraz postaw tworzących skalę preferencji lub pierwszeństwa dla motywów, celów oraz działań podmiotu ${ }^{43}$. Możliwym celem działalności wychowawczej staje się wówczas teocentryczny fundament problematyki miłości małżeństwa - rodziny jako indywidualny, społeczny (kulturowy, duchowy, psychologiczny) cel aksjologiczny.

37 Na przykład aksjologiczno-filozoficzny (David Hume, John S. Mill itd.), teologiczny (Jacek Woroniecki, Tadeusz Styczeń, Mieczysław A. Krąpiec), socjologiczny (np. Florian Znaniecki, Maria Misztal), psychologiczny (Viktor. E. Frankl, Antoni Kępiński), pedagogiczny (Jan Paweł II, Stefan Kunowski, Zygmunt K. Mysłakowski, Bogdan R. Nawroczyński, Katarzyna Olbrycht i in.).

38 Zdaniem Urszuli Ostrowskiej do rozwoju przesłanek konstruujących aksjologię pedagogiczną w Polsce, oprócz Adama Maja, przyczynili się: Krystyna Chałas, Sergiusz Hessen, Janusz Homplewicz, Jan Paweł II, Karol Kotłowski, Stefan Kunowski, Zygmunt K. Mysłakowski, Bogdan Nawroczyński, Katarzyna Olbrycht, Bogdan Suchodolski, Józef Tischner. Urszula Ostrowska, „Aksjologia pedagogiczna - subdyscyplina naukowa pedagogiki (in statu nascendi)”. Roczniki Pedagogiczne 9 (2017): 15-16.

39 Encyklopedia aksjologii pedagogicznej, red. Krystyna Chałas, Adam Maj (Radom: Polskie Wydawnictwo Encyklopedyczne Polwen 2016), 87-91.

40 Maria Misztal, Problematyka wartości w socjologii (Warszawa: Państwowe Wydawnictwo Naukowe 1980), 5.

${ }^{41}$ Mieczysław A. Krąpiec, Dzieła, Metafizyka, Zarys teorii bytu (Lublin: Redakcja Wydawnictw KUL 1995), 5.

42 Misztal, Problematyka wartości, 14.

43 Tamże, 21. 


\section{Zagrożenia i aktualność „miłości - małżeństwa - rodziny” w aksjologicznym nauczaniu i kaznodziejstwie ks. Michalca}

Jak filozofia, będąca „pierwszą” nauką, z charakterystycznego dla niej, największego ze wszystkich nauk, zakresu przedmiotowego wybiera pewną część i o niej traktuje specjalnie ze względu na tej części wagę i wartośćc ${ }^{4}$, tak nauka zwana biografistyką pedagogiczną wybiera przedmiot badań: życie, dzieło, określa wartość etyczną czynu, ukazuje stopień podmiotowego zaangażowania swych postaci. Poprzez rekonstrukcję biograficzną podmiot ujawnić może odpowiedzi na poniższe pytania:

- czym jest dla niego obiektywna „wartość” (problem jej definiowania: Arystoteles, św. Augustyn, św. Tomasz, F. Brentano, Hugo Müstenberg, Andrzej Szostek, Heliodor Muszyński, Karol Kotłowski, Mieczysław Łobocki itd.)?,

- która z wartości ma charakter absolutny, względny, obiektywny, subiektywny, jakie było źródło jej pochodzenia, wartościowania, klasyfikacji, hierarchii, co stanowiło w jego przekonaniu wartość najwyższą?

- jakie normy i wartości zadane, wzory osobowościowe, standardy wychowawcze podmiot akceptował, uznawał za etycznie, społecznie i wychowawczo pożądane, niezależnie od trudności i okoliczności zewnętrznych?

- jak przebiegał proces ich interioryzacji?

Ponieważ zagadnienia kryzysu w wychowaniu, jego przyczyny i skutki są zawsze ważne (we współczesności szczególnie) ${ }^{45}$, w kontekście religijnym podejmował je również ks. J. Michalec. W jego rozumieniu bowiem uniwersalne obowiązywanie wartości chrześcijańskich, posiadających atrybut obiektywizmu i ponadczasowości (aczasowe ujęcie ich aktualności), bywało i jest w dziejach wychowania arbitralnie zawieszane.

W okresie międzywojennym (w latach 1918-1939), gdy do władzy nad narodami europejskimi doszedł zmierzający ku maksymalnej industrializacji, autorytarny bolszewizm, faszyzm, hitleryzm i ich doktryny polityczne, ideologie przeciwne rodzinie chrześcijańskiej, rygorowi „przejściowości” dążącemu do całkowitej eliminacji poddawano głównie autoteliczne wartości: życia, miłości, prawdy, dobra, piękna, wolności, pracy oraz „miłości - małżeństwa - rodziny”. Także socjologowie Charles Fourrier i John B. Watson ${ }^{46}$ zapowiadali „nie-

44 Władysław Tatarkiewicz, Historia filozofii, Filozofia starożytna i średniowieczna, t. 1 (Warszawa: Państwowe Wydawnictwo Naukowe 1981), 13.

45 Mariusz Sztaba, „Rzecz o fundamentalnym wyborze pomiędzy realizmem a idealizmem w tworzeniu adekwatnej koncepcji wychowania”. Roczniki Pedagogiczne 1 (2015): 28.

46 Postaci niewymienione w skorowidzu nazwisk tejże publikacji: Feliks W. Bednarski, Wychowanie młodzieży dorastającej (Rzym: Papieski Instytut Studiów Kościelnych 1976), 286, 288. 
uchronność rozkładu rodziny i zaniku jej wpływu wychowawczego w warunkach społeczeństw uprzemysłowionych i wielkomiejskich" ${ }^{47}$. Destrukcyjne skutki w tym znaczeniu wywołała II wojna światowa (w latach 1939-1945) oraz geopolityczne ustalenia konferencji w Jałcie (4-11 listopada 1945 roku na Półwyspie Krymskim), oddające Polskę pod dominację Związku Socjalistycznych Republik Radzieckich. Zatem po 1945 roku duchowa misja, pedagogia odpowiedzialności i kaznodziejstwo ks. J. Michalca, musiały stać się w państwie polskim zdominowanym przez ZSRR, pozostającym we wrogiej separacji od Kościoła, apologią Boga oraz miłości - małżeństwa - rodziny w komunistycznej przestrzeni aktywnej laicyzacji. Obowiązujący wówczas ideał wychowania socjalistycznego stanowił w PRL naczelną przesłankę formułowania wszystkich celów wychowania ${ }^{48}$. Tym bardziej podjęta przez ks. J. Michalca misja, ujawniając sugestywny sprzeciw wobec eliminowania aksjologicznego znaczenia autorytetu Bożego z szeroko pojętej przestrzeni społecznej, stanowiła naturalną reakcję prawidłowo ukształtowanego sumienia, tj. samoświadomości moralnej (Wojciech Chudy), na postępującą moralną zapaść cywilizacyjną kulturowo chrześcijańskiej Europy. Przejawami kryzysu duchowego było umasowienie socjalizmu, liberalizmu, ateizmu, hedonizmu, egoizmu, zjawisko depersonalizacji, ucieczki w nałogi, uzależnienia i inne „kryjówki” umysłu ludzkiego (ks. Józef Tischner). Ks. J. Michalec ostrzegał przed postępującą antymałżeńską i antyrodzinną, neomarksistowską obyczajowością, ideologią lewicowej „szkoły frankfurckiej”, „rewolucją 1968”. Nie zgadzał się na poniżanie godności człowieka, eliminowanie chrześcijańskiego wychowania religijno-moralnego ${ }^{49}$. Wskazywał na skutki moralno-etycznego i społecznego chaosu, nieodpowiedzialnego traktowania Bożego nakazu nierozerwalności sakramentalnego związku małżeńskiego, podważania niezastępowalności i normatywności funkcji małżonków i rodziców (Frederick Niedhart), wywoływania, pogłębiania, utrwalania wewnętrznego kryzysu rodziny, w tym depopulacyjnej tendencji (niskiej dzietności). Nie dopuszczające „zdrowej nauki” (adekwatnej oceny moralnej) władze państwowe Polskiej Rzeczypospolitej Ludowej, kontrkulturowa zewnętrzna oraz wewnętrzna kontestacja w skali dotąd nieznanej, jej coraz silniejszy konfrontacyjny (antyludzki) charakter, inspirowały księdza do misji obrony tożsamości mężczyzny i kobiety, życia poczętego, związanej z nimi pedagogii ojcostwa, macierzyństwa, powinności (nienarzuconego „obowiązku wewnętrznego" ${ }^{50}$ ) ochrony uniwersalnego modelu pedagogii „miłości - małżeństwa - rodziny”, tj. wartości kwestionowanych jak nigdy dotąd.

${ }^{47}$ Kryzys współczesnej rodziny a wychowanie, w: Bednarski, Wychowanie młodzieży dorastajacej, 42 .

48 Olbrycht, Prawda, dobro, piękno, 26.

49 „Słowo wstępne ks. kardynała Karola Wojtyły arcybiskupa metropolity krakowskiego”, w: Bednarski, Wychowanie młodzieży, 133-154.

50 Stefan Wołoszyn, „Kategoria «powinności» jako podstawowa aksjologiczna kategoria pedagogiki - jak ją rozumieć?”, w: Pedagogika ogólna, 13. 
W przebudowywanym po 1945 roku publicznym systemie oświaty i szkolnictwa polskiego (prywatne szkolnictwo, w tym katolickie, niemal zniszczono), polityczno-ideologiczny paradygmat wychowania wzorowano na bezklasowym, ateistycznym z założenia marksizmie-leninizmie ${ }^{51}$. Nauczanie Kościoła rzymskokatolickiego - przeciwnie - koncentrowało się niezmiennie na religijno-wychowawczym funkcjonowaniu wspólnoty ochrzczonych (wspólnota eklezjalna, monastyczna, społeczna, małżeńska, rodzinna). Od zarania podjętej misji wspierany nauczaniem Kościoła ${ }^{52}$ tenże "nauczyciel-duszpasterz" ${ }^{53}$, wszechstronnie wykształcony w Polsce i poza Ojczyzną, przygotowany duchowo i intelektualnie, edukował katolicką wspólnotę wiernych za pomocą chrześcijańskich wartości obecnych w jego postawie życiowej, nauczaniu: homiliach ${ }^{54}$, kazaniach, wskazaniach, katechezie ${ }^{55}$, katechetyce szkolnej, etycznych normatywach, okolicznościowych pismach, mowach, dygresjach, moralnych radach i opracowaniach naukowych. Fundamentalne podstawy wychowania realizował na podstawie deklaracji o wychowaniu chrześcijańskim Gravissimum educationis z dnia 28 października 1965 roku, która stwierdza, że każdy ma prawo do wychowania.

51 W 1944 roku (październik, grudzień) okólniki resortu oświaty Polskiego Komitetu Wyzwolenia Narodowego „nakazywały przeprowadzenie w szkołach odpowiednio obchodów święta państwowego ZSRR oraz pogadanek o reformie rolnej. Były to pierwsze sygnały upolityczniania szkoły”. Joanna Wojdon, Propaganda polityczna w podręcznikach dla szkót podstawowych Polski Ludowej (1944-1989) (Toruń: Wydawnictwo Adam Marszałek 2001), 14; Sabina Bober, Walka o dusze dzieci i młodzieży w pierwszym dwudziestoleciu Polski Ludowej (Lublin: Wydawnictwo Katolickiego Uniwersytetu Lubelskiego 2011), 300.

52 Adhortacja apostolska Familiaris consortio Ojca Świętego Jana Pawła II do biskupów, kapłanów i wiernych całego Kościoła katolickiego, O zadaniach rodziny chrześcijańskiej w świecie współczesnym, Rzym, 22 listopada 1981 r. (Wrocław: Wydawnictwo Wrocławskiej Księgarni Archidiecezjalnej TUM 1981); Encyklika Piusa XI O chrześcijańskim wychowaniu młodzieży. Divini illius Magistri (Warszawa: Wydawnictwo Te Deum 1999); Gravissimum educationis. Deklaracja o wychowaniu chrześcijańskim (Sobór Watykański II), Przedruk za Sobór Watykański II, Konstytucje, dekrety, deklaracje (Poznań: Wydawnictwo Oficyna Współczesna 2001).

53 „Toteż, przyjmując i zachowując zasady i wskazania z dziedziny argumentacji, nauczyciel-duszpasterz w dziedzinie motywacji na pierwszy plan wysuwać będzie ukazywanie wartości moralnych i prowadzenie wychowanka - ucznia do uznania autorytetów. Aleksander Zienkiewicz, $Z$ problematyki wychowującego nauczania wiary i moralności - argumentacja i motywacja, Uwagi wstępne - fundamentalne. Oprac. z dn. 28 maja 1981r., [archiwum prywatne Ryszarda Małachowskiego].

${ }^{54}$ Homilia (w jęz. greckim: homilein - być razem, rozmawiać) - rodzaj przepowiadania kościelnego, główny przedmiot homiletyki, elementarna funkcja działalności duszpasterskiej Kościoła. Rozróżnia się m.in. typologię homilii: patrystyczną, mistagogiczną, egzegetyczną; homiletyka (w jęz. greckim: homilein, przebywać z kimś, wygłaszać mowę), to dział teologii pastoralnej, zajmujący się teorią i praktyką kaznodziejstwa, zwłaszcza homilii. Encyklopedia katolicka, red. Jan Walkusz, t. 6 (Lublin 1993), 1169-1170.

${ }_{55}$ Katecheza to działalność Kościoła o charakterze dydaktyczno-wychowawczym, kierowana do dzieci, młodzieży i dorosłych, uwzględniająca ich aktualne potrzeby, mentalność, sytuację kulturową, społeczną i religijną. Encyklopedia katolicka, red. Ludomir Bieńkowski, Feliks Gryglewicz, Romuald Łukaszyk, t. 4 (Lublin: Towarzystwo Naukowe KUL 1985), 128. 
Prawdziwe zaś wychowanie zdąża do kształtowania osoby ludzkiej w kierunku jej celu ostatecznego, a równocześnie do dobra społeczności, których człowiek jest członkiem i w których obowiązkach, gdy dorośnie, będzie brał udział. Należy więc zgodnie $z$ postępem nauk psychologicznych, pedagogicznych i dydaktycznych dopomagać dzieciom i młodzieży do harmonijnego rozwijania wrodzonych właściwości fizycznych, moralnych i intelektualnych [...] zmysłu odpowiedzialności [...] prawdziwej wolności ${ }^{56}$.

Wzywając młodzież akademicką (uniwersytecką) do świętości, modlitwy, rachunku sumienia, spowiedzi, ewangelizacji, wdzięczności Bogu za chrzest, realizacji danego jej powołania m.in. w małżeństwie i rodzinie ${ }^{57}$, ks. J. Michalec bronił te wspólnoty przed bezkrytycznym serwilizmem, pesymizmem, nauczał o przyrodzonym i nadprzyrodzonym znaczeniu rodziny, pojmowanej integralnie z chrystologicznie definiowaną miłością i małżeństwem. Przedstawiane wartości, treści, zalecenia, nakazywał i realizował w postawie osobistego świadectwa doktrynalnej wierności Bogu, Kościołowi, wskazaniom Episkopatu Polski, w całkowitym posłuszeństwie ordynariuszowi miejsca. Pomocą w dokonywanej przez niego pedagogizacji wspólnoty ludzkiej jako komunii osób był niezastępowalny wzór Świętej Rodziny z Nazaretu. Potwierdzony autorytetem Pisma Świętego, Tradycją, nauczaniem Kościoła i Stolicy Apostolskiej, wzór ten ciągle zapobiega „ostatecznemu” zniszczeniu małżeństwa i rodziny (ks. kard. Carlo Caffarra, Lúcia Santos ${ }^{58}$ ). Towarzyszy im przecież zasadnicza stałość, a jeszcze bardziej zmiany zagrażające ich istocie i jedności ${ }^{59}$. Dlatego ważny w tym zakresie pozostaje przekaz duszpastersko-wychowawczy ks. J. Michalca, w którym niezbędną rolę pełniło Pismo Święte, obiektywne badania naukowe ${ }^{60}$, wzorotwórcze dzieła

56 Gravissimum educationis, 4-5.

57 Rozdział III. Problemy małżeństwa, 137-173.

58 Lúcia Santos: „Ostateczna bitwa rozegra się o małżeństwo i rodzinę”, za: E.M. Małecka [Katolicka Agencja Informacyjna], „Kuria Rzymska, Kardynał Carlo Caffarra nie żyje”. Nasz Dziennik 207 (2017): 17.

59 Bożenna Balczerzak-Paradowska, Rodzina i polityka rodzinna na przełomie wieków: przemiany, zagrożenia, potrzeba działań (Warszawa 2004); Stefan I. Możdżeń, Fałszywe drogi wychowania, wyd. 1 (Sandomierz: Wydawnictwo Diecezjalne 2013); Elżbieta Kornacka-Skwara, Psychologiczna analiza systemów rodzinnych mężczyzn bezrobotnych (Częstochowa: Wydawnictwo Wyższej Szkoły Pedagogicznej 2004); Maria Braun-Gałkowska, Psychologiczna analiza systemów rodzinnych osób zadowolonych $i$ niezadowolonych $z$ małżeństwa (Lublin: Towarzystwo Naukowe KUL 1992); Rita Grochocińska, Psychospołeczna sytuacja dzieci w rodzinach rozbitych (Gdańsk: Wydawnictwo Uniwersytetu Gdańskiego 1990).

${ }^{60}$ Wychowanie $w$ rodzinie od starożytności po wiek XX, red. Juliusz Jundziłł, Materiały z Konferencji Naukowej Katedry Historii Wychowania (Bydgoszcz: Wydawnictwo Uczelniane Wyższej Szkoły Pedagogicznej 1994); Rodzina polska u progu XXI wieku, I sympozjum naukowe [...] w Łowiczu, 20-21 maja 1996 roku, red. Henryk Cudak (Łowicz: Mazowiecka Wyższa Szkoła Humanistyczna 1996). 
i świadectwa życia biograficznych podmiotów osobowych, motywowanych aksjonormatywną, chrześcijańską inspiracją pedagogiczną ${ }^{61}$.

\section{Miłość aksjonormatywnym fundamentem małżeństwa i rodziny w personalistycznym kaznodziejstwie i pedagogii ks. J. Michalca}

W katolickiej teologii, personalistycznej antropologii i aksjologii ks. Stanisława Kowalczyka, „osoba ludzka [...] jest podmiotem, celem i wartością samą w sobie"62. W personalistycznym ujęciu ks. J. Michalca, kapłana, filozofa, pedagoga, duszpasterza-wychowawcy ${ }^{63}$, człowiek jest wartością i bytem osobowym, "osobnym” od otoczenia, żyjącym „podmiotowym życiem wewnętrznym”, wobec którego „Osobność” człowieka wyznacza nieprzekraczalną „tajemnicę” dostępu. To znaczy, iż do jego wnętrza wniknąć może jedynie on sam, a w stopniu nieskończonym tylko Bóg. Nie można zatem poznać człowieka jako „tajemnicy” osobowej! By zbliżyć się do tegoż „misterium” indywidualnie, w życiu społecznym, „trzeba zdaniem ks. J. Michalca zrezygnować z obojętnej, laboratoryjnej kalkulacji badawczej, beznamiętnego «myślę», na rzecz bezinteresownego «ufam», doprowadzając do autentycznego «spotkania» w duchu miłości bliźniego. Jak długo myśli się interesownie (instrumentalnie), spotkanie staje się niemożliwe, przybierając formę schadzki judaszy i szatanów"64. Przeciwdziałając temu, w pełni życzliwi, cierpliwi, z ofiarnością służebną zaczynamy kształtować relacje, przechodząc od „spotkania” jednostek, do spotkania osób. Stajemy się wówczas za łaską Bożą wzajemnie, i w najwyższym stopniu dla siebie, osobą przybranego syna Boga samego. Trwając na poziomie istot ufających sobie, spotykających się, eliminować należy relacje incydentalne (według ks. J. Michalca „spotkanie

${ }^{61}$ „3. Wychowanie do miłości, małżeństwa i rodziny chrześcijańskiej”, w: Ryszard Małachowski, Działalność wychowawcza księdza Aleksandra Zienkiewicza na Kresach Wschodnich Rzeczypospolitej i Dolnym Śląsku, (Zielona Góra: Oficyna Wydawnicza Uniwersytetu Zielonogórskiego 2013), 448-492.

${ }^{62}$ Kowalczyk, Człowiek w poszukiwaniu wartości, 166. Współczesny personalizm katolicki podkreśla autonomiczną wartość człowieka jako osoby, uznaje osobę za naczelną kategorię poznawczą, metafizyczną i aksjologiczną. Do jego głównych polskich przedstawicieli należą: Roman Ingarden, Karol Wojtyła, Antoni Kępiński, Wincenty Granat, Czesław Strzeszewski, Mieczysław A. Krąpiec, Józef Tischner. Stanisław Kowalczyk, Nurty personalizmu, Od Augustyna do Wojtyty (Lublin: Wydawnictwo KUL 2010), 6.

${ }^{63}$ „Od kiedy [...] pedagogika dowiodła, iż nauczanie z wychowaniem tworzą nierozdzielną całość i że niepodobna uczyć, nie wychowując zarazem "pedagogiem» zaczęto nazywać każdego nauczyciela i wychowawcę wszystkich szczebli hierarchii szkolnej od szkoły początkowej do wyższej, zarówno teoretyków, jak i praktyków". Bolesław Hadaczek, Postać pedagoga w literaturze polskiej (Warszawa - Poznań: Państwowe Wydawnictwo Naukowe 1977), 7.

64 „Wychowanie ku chrześcijaństwu”, w: Michalec, Aby życie mieli, t. 2, 153-154. 
o charakterze momentalnym”), tworząc dojrzałe „wspólnoty” osobowe. Charakteryzuje je wówczas wzajemna gotowość do ofiarności, poświęceń, pełnego przebaczenia, bowiem „przebranie miary w gniewie jest jego upadkiem” (Syr 1, 22). Tylko zawierzanie siebie drugiemu człowiekowi, Bogu, trwałe więzi wspólnotowe należące do kategorii niewidzialnych-duchowych, i tylko taka wspólnota - duchowa, mając status osobowy, może pomóc innym osobom w przejściu z zaciemnienia do wielkiego życia z Chrystusem, w Duchu Miłości i Prawdy. Wychowanie do miłości reflektuje wymóg doskonalenia moralnego. Kościół i świat chrześcijański na przestrzeni dziejów wychowując, podejmował wiele inicjatyw służących takiemu formowaniu człowieka, przygotowaniu go do czynienia dobra inspirowanego miłością. Jest ona osobowym darem, niezbędnym warunkiem „pedagogii Chrystusowej, tj. pedagogii życia z ludźmi w miłości”" ${ }^{5}$. I na tejże „pięknej miłości” jako na chrystologicznej własności natury Bożej, głównej wartości chrześcijańskiej („cnocie”), fundamentalnej, tzn. najwyższej wartości moralnej ${ }^{66} \mathrm{i}$ dobru moralnym, koncentrują się dokumenty i publikacje instytucji Kościoła rzymskokatolickiego (Stolicy Apostolskiej, Urzędu Nauczycielskiego, soborów, synodów), działalność przedstawicieli tegoż kręgu kulturowego ${ }^{67}$ (główne kierunki pomocy, szeroko rozumianego wsparcia), dorobek chrześcijańskich uczonych. Oprócz świętych wszystkich czasów na znaczeniu miłości koncentrowali i koncentrują uwagę badawczą katoliccy naukowcy, w tym teologowie, laikat reprezentujący ważne dla przyjętych rozważań obszary teorii i praktyki pedagogicznej. Podobnie ks. Michalec, analizując miejskie środowisko społeczne i wspólnoty religijne (duszpasterstwa, stowarzyszenia itp.), od dnia święceń

65 Ks. J. Michalec wymienia jeszcze inne pedagogie: „współzawodnictwa, ambicji, przewagi, wiedzy”, tenże, „Miłość bliźniego. Postawa otwartości i życzliwości”, w: Michalec, Aby życie mieli, t. 2, 122; „Rodzina jako szkoła miłości”, w: Magdalena Parzyszek, Rodzina w nauczaniu kardynała Stefana Wyszyńskiego, Aspekt pedagogiczny (Lublin: Wydawnictwo KUL 2012), 65-67.

${ }_{66}$ Aleksander Zienkiewicz, Miłości trzeba się uczyć. Rady dla młodych (Wrocław: Oficyna Współczesna, 1994), 5.

${ }_{67}$ Miłość potężniejsza niż śmierć - potężniejsza niż grzech. Dives in misericordia, Encyklika Ojca Świętego Jana Pawła II o Bożym miłosierdziu (Warszawa: Wydawnictwo Ośrodka Dokumentacji i Studiów Społecznych 1981), 33-38; „Droga miłości [83]”, w: Posynodalna adhortacja apostolska Ecclesia in Europa Ojca Świętego Jana Pawła II. Do biskupów, do kapłanów i diakonów, do zakonników i zakonnic oraz do wszystkich wiernych o Jezusie Chrystusie, który żyje w Kościele, jako źródto nadziei dla Europy (Wrocław: Wydawnictwo Wrocławskiej Księgarni Archidiecezjalnej TUM 2003), 101-102; „Zdecydujmy się na miłość”, w: Posynodalna adhortacja, 121-122; Encyklika Deus caritas est Ojca Świętego Benedykta XVI. Do biskupów, prezbiterów i diakonów, do osób konsekrowanych $i$ wszystkich wiernych świeckich o miłości chrześcijańskiej (Kraków: Wydawnictwo M 2006); Karol Wojtyła, Miłość i odpowiedzialność (Lublin: Towarzystwo Naukowe KUL 1986); Walter Trobisch, Miłości trzeba się uczyć (Częstochowa: Wydawnictwo Misjonarzy Krwi Chrystusa - Pomoc 1999); „Największa jest miłość”, w: Aleksander Zienkiewicz, Kazania i homilie na różne okazje, red. Jadwiga Wartalska (Kraków: Wydawnictwo OO. Franciszkanów Bratni Zew 2006), 202; Zienkiewicz, Miłości trzeba się uczyć, 30; Tadeusz Styczeń, Urodziłeś się by kochać (Lublin: Towarzystwo Naukowe KUL 1993); Mieczysław Maliński, Zanim powiesz kocham (Szczecin: Wydawnictwo Ottonianum 1990). 
kapłańskich wskazywał na jedno z podstawowych zadań kapłana, duszpasterza-wychowawcy, tj. na przygotowanie młodzieży do życia w miłości jako godziwej postawie moralnej, szczęśliwej małżeńskiej i rodzinnej communio sacramentalis, tj. wspólnocie wartości sakramentalnych.

Według Sługi Bożego ks. Aleksandra Zienkiewicza ${ }^{68}$ misyjny nakaz Jezusa Chrystusa skierowany do kapłanów: „Idźcie i nauczajcie”, w przeciwieństwie do pospolitych czynności, jest dziełem o szczególnej, wyjątkowej wartości i sensie. Bowiem Kościół ze swej natury stanowi wspólnotę misyjną i to Duch Święty jest prawdziwym i jedynym sprawcą misji Kościoła i kapłana. W tymże pneumatologicznym, „chrześcijańskim powołaniu mieści się [...] misja” ${ }^{69}$, a szczególnie „nadprzyrodzona misja"70 kapłana i duszpasterza-wychowawcy jednocześnie. Na jej fundamencie ks. J. Michalec z prawdziwą troską pytał rodziców i młodzież: czy wartości takie, jak wiedza, wychowanie w zakresie katolickiej miłości, małżeństwa, rodziny stanowią jeszcze podstawę polskiej kultury narodowej, wychowania społeczeństwa, narodu i funkcjonowania państwa? ${ }^{? 1}$ Konstatował bowiem, iż przestrzeń i środowiska, które najbardziej sprzyjały wychowaniu „młodego człowieka”, nie zawierają już niczego „z tego klimatu”, którego doświadczał w przeszłości. Materialistyczna aksjologia socjalistycznego państwa, trwanie w separacji wrogiej do Kościoła, prymat spraw ziemskich (doczesnych), hedonizm, powierzchowny emocjonalizm, antyintelektualizm, w znacznej mierze usunęły z przestrzeni prywatnej oraz publicznej wychowanie ku Bogu i ludziom. Przez to człowiek coraz częściej mówi drugiemu człowiekowi: „nie czekaj już na moją miłość”72.

Dlatego Erich Fromm, autor książki $O$ sztuce miłości, Walter Trobisch, ks. Zienkiewicz, współpracujący z nim ks. J. Michalec, zachęcali do kształcenia (edukacja aksjologiczna) i wychowania (działania wychowawcze) ku wartościom. Bowiem prawdziwej „miłości trzeba się uczyć”73, trzeba formułować pytania

68 Po dopełnieniu wymaganych prawem kościelnym procedur badawczych 25 listopada 2017 r. zakończono w Archidiecezji Wrocławskiej etap diececzjalny prac prowadzących do wyniesienia na ołtarze Sługi Bożego ks. Aleksandra Zienkiewicza. List z dnia 7 listopada 2017 r. skierowany do Ryszarda Małachowskiego zapraszający do uczestnictwa w uroczystościach zamknięcia powyższego etapu, podpisany przez Arcybiskupa Metropolitę Wrocławskiego + Józefa Kupnego, k. 1.

${ }_{69}$ Świętymi bądźcie. Orędzia Ojca Świętego Jana Pawła II na Światowe Dni Młodzieży, red. Henryk Tomasik, wyd. 1 (Częstochowa: Biblioteka „Niedzieli”, t. 137, 2002), 145.

70 Aleksander Zienkiewicz, Wzrastać w światłości. Stawać się chrześcijaninem. Stawać się księdzem. Zbiór kazań, red. Jadwiga Wartalska (Kraków: Wydawnictwo OO. Franciszkanów Bratni Zew 2000), 14.

${ }^{71}$ Uzasadnienie takie wynika z analizy nauczania kard. St. Wyszyńskiego dotyczącego rodziny jako fundamentu narodu i państwa, w: Parzyszek, Rodzina w nauczaniu, 158-171; „Zagrożenia życia rodzinnego (ateizm, laicyzacja, alkoholizm, rozwody, spadek liczby urodzeń, zagrożenie wewnętrzne, moralność antykoncepcyjna, lenistwo, lekkomyślność, marnotrawstwo)", tamże, 173-188.

72 „Człowiek w oczekiwaniu Boga”, w: Michalec, Aby życie mieli, t. 2, 135.

73 „Miłość przyjaźni i caritas”, tamże, 138. Sformułowanie użyte przez ks. J. Michalca „miłości trzeba się uczyć" ma swoje odpowiedniki. Pod tym samym tytułem ukazała się 36-stronicowa publikacja Waltera Trobischa pt. Miłości trzeba się uczyć; A. Zienkiewicza, Miłości trzeba się uczyć. 
fundamentalne dla odkrywania i zachowania jej istoty, człowieczeństwa małżonków, integralności małżeństwa, rodziny, rodzicielstwa, macierzyństwa, ojcostwa, społeczeństwa i świata. Poszukując słowa odpowiedniego do myśli, ks. J. Michalec konstruował sytuacje problemowe, pytając: czym jest miłość, i odpowiadał: miłość Boża - fundamentalna jest jedyną wartością w swej nieskończonej doskonałości. Przybliżał jej postaci skierowane ku Bogu i bliźniemu, jej początek będący uszanowaniem i okazywanym szacunkiem, wskazywał rodaje: miłość przyjaźni, caritas, miłość seksualną, erotyczną (eros - sprawca miłości erotycznej ${ }^{74}$ ), miłość „upodobania”. Ale nauczał, iż miłość fundamentalna stanowi jedyny autentyczny (szczery), możliwy sposób realizacji „stanu przeżywania” miłości ${ }^{75}$, bogactwa postaw („nastawień” moralnych) skierowanych do drugiego człowieka, od życzliwości - do oddania życia. Tylko tam, gdzie imperatywem działania była prawdziwa miłość, powstawały dzieła jednostek, wspólnot, małżeństw i rodzin (np. polskich, ratujących Żydów w czasie II wojny światowej), oraz ludzkości naprawdę godne podziwu. Zatem oprócz wychowania „do miłości” istnieć musi „wychowanie miłości”76, będące zadaniem skierowanym do sumienia jej podmiotów jako najważniejszej instancji wychowawczej (W. Chudy).

W opinii Chudego zadanie to wspiera nieustannie „Opatrzność”, czyli realna rzeczywistość łaski, podobnie skutkuje realizacja „normy personalistycznej” Karola Wojtyły, w myśl której żaden człowiek nie może być przedmiotem reifikującego użycia ze strony drugiej osoby. W parze $\mathrm{z}$ tym idzie treść pozytywna normy wyjaśniająca, iż: „osoba jest takim dobrem, że właściwe i pełnowartościowe odniesienie do niej stanowi tylko miłość. I tę właśnie pozytywną treść normy personalistycznej eksponuje przykazanie miłości"77. W odniesieniu do niej prawdziwa miłość musi być zdaniem ks. J. Michalca miłością całkowitą (zupełne poświęcenie się), bardzo trudną (heroiczną), ale prawdziwie wolną, nieustannie uzdrawianą i wzmacnianą tylko dzięki wierze w Jezusa Chrystusa Miłosiernego. „Jaka jest bowiem Jego wielkość, takie też i Miłosierdzie"78. Nie ma przecież zdrowej miłości bez miłosierdzia Bożego. Tak zintegrowana w Bogu potrafi trwać we wspólnocie ze Stwórcą, człowiekiem i społeczeństwem. Za jej sprawą największy trud z nią związany staje się ostatecznie niezmiernie łatwy w realizacji. Dzięki postawie miłości człowiek pragnie dobra, pełni szczęścia dla drugiej osoby, bo

74 „Miłość erotyczna, miłość upodobania”, w: Michalec, Aby życie mieli, t. 2, 139.

75 Miłość przyjaźni i caritas, 137. Kategorię „przeżywania” wprowadza również w swym studium moralno-etycznym Karol Wojtyła (tenże, Miłość i odpowiedzialność, 13).

76 Wojciech Chudy, Pedagogia godności. Elementy etyki pedagogicznej (Lublin: Towarzystwo Naukowe KUL Jana Pawła II 2009), 129. „Wychowanie miłości i do miłości w istocie polega [...] na rozwoju osoby jako osoby. Nie można doskonalić miłości, deprecjonując człowieka”, w: Chudy, Pedagogia godności, 130.

77 Wojtyła, Miłość i odpowiedzialność, 42.

78 Syr 2, 18. 
miłość jest stanem „czujnej uwagi”79 skierowanej ku podmiotowi. O niej to William Morris napisał poemat pt. Miłość wystarczy... „tylko niestety nie każda” (ks. J. Michalec), „bo urok marności przesłania dobro, a burza namiętności mąci prawy umys”" ". Tak więc jeśli nawet to, co do miłości prowadzi i stanowi dobrą do niej drogę, miłością jeszcze nie jest, to na pewno miłością nie jest zerwanie przez narzeczonych i małżonków pełnej relacji z Bogiem. Owa separacja demaskuje egocentryczną autonomię, ubóstwianą samowystarczalność istot ludzkich, zreifikowany seks („cielesny poryw”), związane z nim afekty instrumentalnie towarzyszące miłości, będące jej zaprzeczeniem. Miłość nie krzyczy: „co ja z ciebie mam!?”. Nie jest nią moda na „zmysłowość” wolną od etycznej kontroli rozumu. Nawet szlachetne i niebezpieczne akcje misyjne, akty miłosierdzia nie spełniają tego warunku, jeśli nie budzą pełnej szacunku miłości człowieka do Boga.

\section{Małżeństwo i rodzina aksjologicznym środowiskiem wychowania do miłości w duszpastersko-wychowawczej pedagogii ks. J. Michalca}

W zintegrowanym nauczaniu wychowującym ks. J. Michalca pojawiają się próby odpowiedzi na podstawowe pytania: czym jest sakramentalna rodzina, małżeństwo, jaka jest ich geneza, cele, komu i czemu służą, jakim wartościom, na czym się opierają, jakie pełnią funkcje, dokąd prowadzą, tzn. jaki jest rodziny i małżeństwa naturalny i nadnaturalny sens? Z punktu widzenia katolickiej etyki małżeńskiej nauczał, iż chrześcijańskie małżeństwo monogamiczne stanowi sakramentalny związek dwojga osób: mężczyzny i kobiety, aksjologiczne środowisko wychowania do miłości, będące najważniejszym wzorem, celem wychowawczym, posiadającym fundament chrystologiczny z powodu Osoby Jezusa Chrystusa. Rzeczywistość małżeńska i rodzinna oparta na tym fundamencie, którym jest Jego miłość, winna stać się trwałym „przeżyciem religijnym”"1 (swoisty „locus theologicus”"82),

79 „Łączność z Panem Bogiem przez intencję - stan świadomości”, w: Michalec, Aby życie mieli, t. 2, 99.

$80 \mathrm{Mdr} 4,12$.

81 „Przeżycia religijne” złożone $\mathrm{z}$ „aktów religijnych” (religijno-moralnych), to dwa pojęcia, których nie wolno zdaniem ks. J. Michalca utożsamiać. W jego przekonaniu „religia” (poszczególne jej akty) nie dotyczy przede wszystkim problematyki poszanowania prawa Bożego, lecz wybrania Boga przez człowieka. Wyprowadza z owej przesłanki taką oto konkluzję, że zgoda człowieka będąca aktem przyzwalającego wyboru jest aktem wtórnym, gdyż to Bóg zawsze pierwszy wybiera nas (Jan Miodek, „Ksiądz Julian Michalec”, w: Ks. Julian Michalec, 43).

S. Kowalczyk pisze, iż Karol Wojtyła, używając terminu „przeżycie”, utożsamia „doświadczenie moralne” z „przeżyciem dobra i zła moralnego”. Tenże, Z refleksji nad człowiekiem, 24-25.

82 „Locus theologicus” - termin mający podstawowe znaczenie dla poznania teologicznego, spopularyzowany w Europie przez hiszpańskiego scholastyka z czasów soboru trydenckiego Melchiora Cano (1509-1560), który mówi, że „loci theologici stanowią źródła teologii zawierające 
chrystocentrycznym w życiu codziennym jej członków. Wskazując na wybrane cele małżeństwa, najpierw pośrednie: wzajemną miłość, współpracę, zrodzenie i wychowanie potomstwa, „z odwiecznego postanowienia Boga” przez sumienie $^{83}$ i nauczanie Kościoła - Jezus Chrystus nakazuje, by wszystkie służyły celowi nadrzędnemu, tzn. moralnemu wzrostowi dwojga ludzi. „Wszelkie małżeństwo tak pojęte i tak podjęte jest dobre, wszelkie zaś, choćby dwojga nieprzytomnie zakochanych, w żaden sposób nie zbliżające do Chrystusa nie spełnia nadrzędnego celu małżeństwa" ${ }^{84}$. Nie służy tylko realizowaniu wzajemnych życzeń, poleceń i próśb małżonków, będąc dobrowolnym związkiem wyboru i uznania, lecz jest „najskuteczniejszym narzędziem humanizacji i personalizacji” ${ }^{85} \mathrm{w}$ rodzinie. Momentem poprzedzającym miłość, małżeństwo i rodzinę jako wartości, jest spostrzeżenie przyszłego małżonka jako jedynej wartości pośród wielu innych osób. Przejście tych osób od stanu spostrzeżenia wartości do stanu miłości ujawnia główne kryterium jego zawarcia, wyrażające się dojrzałością moralną, jednością, stałością, odpowiedzialnością, wiernością, wyłącznością, otwartością, życzliwością „nierozerwalnością”"

Zdaniem W. Chudego „małżeństwo jest wielką domeną wychowawczą współmałżonków, oddziałujących na siebie, tj. na własne osobowości pedagogicznie, w celu uczynienia miłości oblubieńczej „cnotą”. Wiąże się z jej rozumieniem problem odpowiedzialności za dar tejże miłości i małżeństwa, która nie ogranicza się do troski o byt, ale także do odpowiedzialności, która „jest raczej staraniem wewnętrznym, aby trwała i rozwijała się wartość daru, zapoczątkowana we

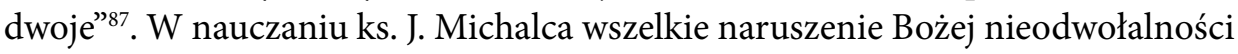
złączenia natury ludzkiej i jej praw w sakramencie małżeństwa, nienaruszalności ich wewnętrznej jedności (stałości), spotyka się ze stanowczym zakazem: „nie wolno!”. Bowiem zarówno natura mężczyzny, jak też kobiety, ze względu na dopełniające ich różnice, komplementarność, w jednym domaga się szczególnie tego samego: uczynienia z małżeństwa - aż do śmierci - naturalnego „miejsca” ich całożyciowej, trwałej egzystencji, pełnego bezpieczeństwa, spełniania w tych zakresach wyznaczonych zadań oraz wszechstronnego rozwoju. Ofiarność mężczyzny bierze inspirację i motywację z fenomenu kobiecości, zadziwiającej subtelności, nadzwyczajnego poświęcenia, służebności, delikatności szukającej oparcia w wierności mężczyzny, mężnej czystości i stałości jego charakteru, w harcie i sile.

pewne, tym samym niezawodne pod względem teologicznym i aprobowane ogólnie zdania" (Jan Sochoń, „Teatr jako miejsce teologiczne. Wizja Tadeusza Kantora”. Ethos 1-2 (2007): 113).

83 Cytując za Wojciechem Chudym, „sumienie [...] jest samoświadomością moralną człowieka" (tenże, Pedagogia godności, 95).

${ }^{84}$ „Nadrzędny cel małżeństwa i rodziny”, w: Michalec, Aby życie mieli, t. 2, 144.

85 List do rodzin Ojca Świętego Jana Pawła II, Rok Rodziny 1994, reprint (Wrocław: Libreria Editrice Vaticana, Wydawnictwo Wrocławskiej Księgarni Archidiecezjalnej 1994), 80.

86 Athanasius Schneider, „Proroczy głos. Czterech kardynałów świętego Kościoła rzymskokatolickiego", przeł. z ang. Jadwiga Stachurska. Nasz Dziennik 285 (2016): 12-13.

87 Chudy, Pedagogia godności, 148. 
Dzięki tym cechom i innym uzdolnieniom mężczyzna poniesie ofiarę ze swego życia, by zaspokoić - nawet w zagrożeniu - naistotniejsze potrzeby materialne małżonki i potomstwa, zapewnić im niezawodną obronę. Ona odwzajemni mu większą od mężczyzny - zadziwiająco piękną wytrwałość, wytrzymałość na trudy tegoż życia rodzinnego oraz doświadczenia losu ${ }^{88}$. Biorący w obronę wszystkie małżeństwa i rodziny Boży zakaz wyrażający się w radykalnym: „nie wolno!” stoi w opozycji do lekceważenia ludzkiej natury, niezabezpieczania koniecznych podstaw egzystencji w zakresie duchowo-materialnym i religijnym wspólnoty rodzinnej, zakłócania rozwoju wrodzonych skłonności małżonków służących realizacji miłości i zabezpieczeniu „autorytetu słów Chrystusa”. Jeśli Jezus Chrystus mówi: „Non possumus!”, Jego odwieczne decyzje, przestrogi jako nieskończone dobro, znajdują się poza wszelką dyskusją, nieufnością (niedowierzaniem). Poza wszelką dyskusją znajduje się wspomniana nierozerwalność małżeństwa, co do którego ks. J. Michalec konsekwentnie twierdził, iż decyzję o małżeństwie poprzedzać musi bezwzględne wykluczenie rozwodu pomimo obaw, lęku o to, czy będzie udane i szczęśliwe. Nauczał, iż tylko małżeństwa pozbawione rzeczywistego życia religijnego z Chrystusem nie będą potrafiły wytrwać w jedności i wierności. Jednak „batalia” o nierozerwalność małżeństwa trwać będzie „do końca życia Kościoła" ziemskiego ${ }^{89}$. O ile wierność w nim jest wynikiem miłości, o tyle „miłość mierzy się stałością" ${ }^{\circ}$. Stałość jest przesłanką informującą o wartości istoty ludzkiej, w realizacji dobra kształtuje wytrwałość w życiu, wierze, modlitwie, obowiązku. Także jedność i wyłączność zabezpieczają: miłość, małżeństwo i rodzinę. W przeciwnym wypadku zmysłowość (eros), afekty składające się na stan tzw. zakochania, utożsamiane $\mathrm{z}$ „sakramentem natury”, który wszystko rzekomo usprawiedliwia, mogą z miłości, małżeństwa, rodziny - jako ogrodu - uczynić według ks. J. Michalca „dziki gąszcz”, miejsce „wiecznego skazania" ${ }^{\text {, }}$, piekło na ziemi92.

Rodzina, będąca podstawowym środowiskiem miłości, bierze początek w miłości, jaką Stwórca ogarnia stworzony świat. Dzięki zmianie ontycznej, tj. poczęciu dziecka, jego zaistnienie zmienia małżeństwo w rodzinę. Żona staje się dla męża oraz dzieci matką, rozmówczynią, odważną nauczycielką, mąż dla żony - ojcem jej potomstwa i głosicielem „Dobrej Nowiny”, „obydwoje stają się osobami we własnej rodzinie" ${ }^{\prime 3}$. Z powodu szczególnej relacji z dzieckiem i szczególnej odpowiedzialności za wychowanie religijne potomstwa rola matki wspieranej przez męża - jest w tym zakresie pierwszoplanowa, zwłaszcza w początkowym okresie życia. Oprócz tego, że rodzina stanowi niezbywalną wartość,

\footnotetext{
88 „Nierozerwalność małżeństwa”, w: Michalec, Aby życie mieli, t. 2, 147.

89 Tamże, s. 148.

90 Miodek, „Ksiądz Julian Michalec”, 41.

91 „Drogi miłości: miłość seksualna i erotyczna”, w: Michalec, Aby życie mieli, t. 2, 142.

92 Paul Evdokimov, Gogol i Dostojewski czyli zstąpienie do otchłani, przeł. Adriana Kunka (Bydgoszcz: Wydawnictwo Homini 2002).

93 Chudy, Pedagogia godności, 154.
} 
pierwszą szkołę wychowania, uspołecznienia i pokoju", ks. J. Michalec pojmuje „rodzinę chrześcijańską” ze wszystkimi tego konsekwencjami aksjologicznymi: filozoficzno-kulturowymi, teologicznymi, antropologicznymi (stworzenie człowieka przez Boga, odczytanie jego tożsamości w Tajemnicy Trynitarnej, udział w Bożej naturze, dialogicznej strukturze osoby ludzkiej, indywidualnej i społecznej egzystencji). Łączy ją ze skutkami sakramentalnymi, moralno-etyczny$\mathrm{mi}$, pedagogicznymi, duszpastersko-wychowawczymi, nieuniknioną kontestacją i konfrontacją polityczną, także etyczną z wieku XX i XXI (profetyczna ponadczasowość refleksji ks. J. Michalca). Dar, tajemnica rozwoju, „bogactwo człowieczeństwa” z niej wynikające, kierowały go ku postawie „najgłębszego zadziwienia” nad jej fenomenem, w zakresach, jakie umysł ludzki może wyznaczyć. Wskazywał, iż wszystko, co dobre, również rodzina, początek ma w Bożej Miłości, wzór w Świętej Rodzinie z Nazaretu mówiący badaczom nieskończenie więcej niż tysiące opracowań naukowych, zwykłych książek, codziennych publikacji prasowych. Założenie jej wymaga odpowiedzialnego, roztropnego namysłu, miłości kandydatów, mądrości, kultury wyboru, prawdziwej miłości Bożej, która u Boga nigdy nie ustaje. U człowieka miłość ma skłonność do „umierania”, przed czym zabezpieczyć ją może trwanie rodziny w postawie całkowitej równości małżonków przed Trójcą Świętą i sobą nawzajem, szacunku, wzajemnym wybaczaniu, nieustannej pracy nad jej trwaniem. Stanowiąc nierozerwalną, religijną wspólnotę ciężko wypracowanej jedności, małżonkowie dzięki doskonałemu poznaniu i darowi $\mathrm{z}$ siebie, świadomi dobrowolnego fundamentalnego wyboru powinni ${ }^{95}$ ofiarnie, cierpliwie, wieloaspektowo wychowywać i edukować się nawzajem, wraz z dziećmi, do życia w niej samej.

W porządku natury posiadanie rodziny jest normą, i w tym znaczeniu każdy ma i musi mieć rodzinę. Trudno wyobrazić sobie człowieka bez rodziny, gdyż Stwórca nie poddał nas prawom zwierząt, ofiarując nam wielopokoleniowe "gniazda rodowe”. Za pośrednictwem rodziców ziemskich otrzymaliśmy życie, imiona, nazwiska, a nie bezimienne numery ewidencyjne (historia i współczesność obozów koncentracyjnych). Chociaż indywidualną oryginalność, dobroć, szlachetność, ale i zło wynieść można także z rodziny, zadziwiającego „łańcucha rodzin” tworzących ludzkość, ks. J. Michalec nazywał wspólnotę rodzinną niczym niezastąpioną szkołą cnót: „bogactwa człowieczeństwa”, „przeżyć religijnych" i religijności, codziennego pacierza, szlachetności, uczciwości, cech zdobytych w rodzinie i przez rodzinę. Funkcjonowanie jej ma wymiar nadprzyrodzony i przyrodzony służący uzupełnianiu się małżonków, biologiczny - dla zrodzenia potomstwa, godziwej regulacji urodzin, pedagogiczny - w celu wychowania

94 Kobieta wychowawczynią do życia w pokoju, Orędzie Jego Świątobliwości papieża Jana Pawła II na XXVIII Światowy Dzień Pokoju, wygłoszone 1 stycznia 1995 roku, 9.

95 Powinność to „obowiązek wewnętrzny” - nie narzucony, za: Wołoszyn, „Kategoria «powinności»", 13. 
dzieci, także adoptowanych („poszerzone braterstwo”). Każde jednak z „przeżyć religijnych", czynów człowieka i instytucji ludzkich, szczególnie instytucja rodziny jest głównie i przede wszystkim po to, by ten, kto jest jej uczestnikiem, „wzrastał w łączności z Jezusem Chrystusem”. „Po chrześcijańsku pojęta rodzina to ta, która z kulturą miłości łączy kulturę życia religijnego" 96 i kulturę wychowania. Stąd nauczanie duszpastersko-wychowawcze ks. J. Michalca zawiera przestrogę, iż każde spotkanie ludzi może doprowadzić do powstania wspólnoty ludzkiej albo zbiorowiska szatanów - antywspólnoty nienawiści i nieufności.

Co się bowiem stanie, jeśli to spotkanie okaże się zagrożone: przyjdzie wojna, zburzą, podpalą dom, kościół, szkołę, biblioteki, kino, teatr, operetki, opery, a woda zapomni „o swej własności gaszenia?”97. Jeśli człowiek zniszczy władzę, państwo, naród, społeczeństwo (które winno wychowywać), jednostkę? Gdy rodzinę zrujnuje brak miłości, odpowiedzialności, zdrada, rozwód, bieda, patologia, deprawacja, zepsute słowo? „Bo i skryte słowo nie jest bez następstwa”"98. Jakże głęboki imperatyw wynika wtedy - zdaniem ks. J. Michalca - z sentencji Solona wypisanej nad portykiem świątyni Apollina w Delfach: „Gnothi seauton - poznaj samego siebie. I wychowuj samego siebie”. Bo jeśli rodzice, wychowawcy z dyplomem studiów wyższych czy „najwyższych” (teoretycy i praktycy wychowania), nawet kapłani, nie znają siebie i wychowanka, to wówczas tchną "groteską" i klęską. Warunkiem powodzenia pracy wychowawczej jest bowiem samopoznanie i samowychowanie pedagoga, wytrwałość, czyli cierpliwość, tak pomijana świadomość, konieczność wspomagającej łaski Bożej. Oprócz tego trzeba się interesować wychowaniem jako długotrwałym procesem, w którym rodzina współpracuje z Kościołem. Należy wiedzieć, ku jakim wartościom prowadzimy siebie i wychowanka przez całe życie. Toteż z obserwacji życia społecznego ks. J. Michalec bezkompromisowo wyprowadza odważne wnioski, twierdząc, iż po niemal dwudziestu wiekach istnienia Kościoła należy opracować dokument soborowy o wychowaniu chrześcijańskim, gdyż wychowanie oficjalne w Polsce (w 1976 roku) ma nadal charakter ateistyczny, a rodzina znajduje się pod wpływem rozległych przemian społecznych i kulturowych ${ }^{99}$. Społeczeństwo owładnięte zachodnimi ideami permanentnego dobrobytu, wygody, emanuje brakiem entuzjazmu wiary, konsekwencji chrześcijańskiej, podczas gdy osamotnieni duchowni tracą zdolność do wychowywania w radości. Kto siebie i drugiego wychowuje, największego dzieła ludzkości dokonuje, „kto zaś siebie i drugiego wychowuje $\mathrm{w}$ stanie łaski, w zjednoczeniu z Jezusem, ten już tu na ziemi

96 „Przez rodzinę do człowieczeństwa”, w: Michalec, Aby życie mieli, t. 2, 146.

97 Mdr 19, 20,

98 Mdr 1, 11.

99 Adhortacja apostolska Familiaris consortio Ojca Świętego Jana Pawła II do biskupów, kapłanów i wiernych całego Kościoła katolickiego, O zadaniach rodziny chrześcijańskiej w świecie wspótczesnym, Rzym, 22 listopada 1981 r. (Wrocław: Wydawnictwo Wrocławskiej Księgarni Archidiecezjalnej TUM 1981), 3. 
dokonuje dzieła Boskiego"100. Wobec powyższego jako człowiek, Polak, kapłan Krzyża Chrystusowego, duszpasterz-wychowawca w konkluzji stanowczo oznajmiał: doświadczanie ${ }^{101}$ Boga w „przeżyciu religijnym” wynikającym z kerygma$\mathrm{tu}^{102}$ : „Ja Jestem Droga, Prawda i Życie” ${ }^{103}$ jest jedyną prawdziwą drogą, prowadzącą do osiągnięcia trwałej łączności z Bogiem i Jego pedagogiczną Obecnością. Przeżycie religijne stanowi szczególnie ważny aksjologicznie czynnik wychowawczy. I to przede wszystkim ten czynnik przygotowuje młodzież do realizacji zasad miłości - małżeństwa - rodziny jako wartości chrześcijańskich.

\section{Zakończenie}

W finalnej części badań podmiotu i przedmiotu, wyznaczając „kres” działalności człowieka, Księga Mądrości mówi: „Czas nasz jak cień przemija, śmierć nasza nie zna odwrotu”"104. I oto dnia 18 lipca 1988 roku odszedł ks. Michalec, pozostawiając kluczowe przesłanie wychowawcze, które można analogicznie odnieść do słów św. Jana Pawła II Wielkiego: „wychowanie jest [...] przede wszystkim obdarzaniem człowieczeństwem"105. Wychowanie świadomie aksjologiczne prowadzi do przekonania, iż „żaden człowiek nie może usytuować się poza światem wartości

100 Michalec, Aby życie mieli, t. 2, 159. Roman Ingarden, Przeżycie, dzieło, wartość (Kraków: Wydawnictwo Literackie 1966).

101 „Doświadczenie religijne zawiera w sobie elementy poznawczo-intelektualne, wolicjonalne, etyczne i emocjonalne. W definicjach teologicznych podkreśla się różne jego aspekty (ontologiczne, aksjologiczne, podmiotowe, przedmiotowe), zaznaczając zarazem, że doświadczenie to nie tyle jest domeną poznania, ile egzystencjalną postawą człowieka względem Boga. W sensie ścisłym pojęcie to odnosi się do posiadających wyraźne odniesienie do Boga intensywnych przeżyć religijnych, takich jak: konwersja, przeżycia mistyczne, objawienia. W sensie szerokim - do wszelkich ludzkich zachowań ukierunkowanych na sacrum (życie religijne - modlitwa, kult, wiara). W tym ujęciu dochodzi do utożsamienia pojęć doświadczenie religijne, przeżycie religijne, akt religijny. Dla potrzeb tej pracy przyjmujemy szerokie rozumienie omawianego terminu”. Grzegorz Cyran, „Doświadczenie judasza w pedagogii wiary”, w: Język doświadczenia religijnego, red. Grzegorz Cyran, Elżbieta Skorupska-Raczyńska, t. 3 (Szczecin: Wydawnictwo Volumina pl Daniel Krzanowski 2010), 408.

102 Kerygmat - w jęz. greckim: proklamacja, obwieszczanie publiczne, ogłaszanie, treść i czynność głoszenia. Jest orędziem zbawienia dokonanego i objawionego przez Boga w Jezusie Chrystusie, głoszonym, przepowiadanym w Jego imieniu, weryfikowanym, potwierdzonym, strzeżonym w Kościele dzięki asystencji Ducha Świętego, w celu nawrócenia i zbawienia ludzkości (ewangelizacja). Encyklopedia katolicka, t. 8, 1359.

103 „Religijność z człowieka wydobyta”, w: Michalec, Aby życie mieli, t. 1, 19; Jak przypomina Ireneusz Ziemiński: „Wprawdzie mistrz jest autorytetem dla ucznia, to jednak dla obu autorytetem jest prawda, mistrz zaś stanowi jedynie pomocniczy do niej drogowskaz. Do pewnego stopnia mistrz musi zatem stać się niewidzialny, tak aby mógł ukazać to, co istotne. Zgodnie z trafną uwagą Martina Bubera mistrz uczy tak, jakby nie uczył; uczy samą swoją obecnością, którą dostrzegamy zwykle dopiero wtedy, gdy go zabraknie”. Ireneusz Ziemiński, „Sumienie nauki, O roli mistrza w kształceniu uniwersyteckim”. Ethos 1-2 (2009): 70.

104 Mdr 2, 5.

105 List do rodzin Ojca Świętego, 58. 
uniwersum antroposferycznego, którego jest konstytutywną cząstką"106, które kształtują go osobowo. Jak uzasadnia Katarzyna Olbrycht, wartości w wychowaniu nie mogą być ideologicznym sztafażem, niepogłębioną, ogólną deklaracją intencji, niewartą podejmowania poważnych dyskusji ${ }^{107}$. Podobnie ks. J. Michalec w opinii wychowanków „święty kapłan”, „apostoł Świętej Rodziny”, edukując, wskazywał na kształtujące go zinternalizowane, wychowawcze doświadczenie wartości. Historiozoficzne znaczenie dostrzegał w traumatycznych „przeżyciach” konspiracyjnych z okresu II wojny światowej (w latach 1939-1945), utracie ojczystych Kresów Wschodnich i niepodległości Polski, okupacjach, represjach, ideologiach totalitaryzmu niemieckiego i radzieckiego ${ }^{108}$. Dlatego w danym mu czasie roztropnie chronił wychowanków, małżeństwa, rodziny przed błędną aksjologią i antropologią marksistowską, egzemplifikowaną polskim odpowiednikiem "homo sovieticus”, ateistyczną indoktrynacją PRL, ideologiami przyszłości. Wyjaśniając sens chrześcijańskiej miłości - małżeństwa - rodziny, poza głównym: teologicznym, teocencentrycznym, pneumatologicznym, mariologicznym, józefologicznym charakterem, ukazywał aksjologiczne znaczenie takiego wychowania. Podkreślał bezwzględny i obiektywny charakter życia ${ }^{109}$, wiary, nadziei, miłości, cierpienia, miłosierdzia, ufności, prawdy będącej dobrem i pięknem ${ }^{110}$.

Za pomocą użytych treści, dyscyplin, metod, środków naukowych, przez dziesięciolecia (w latach 1949-1988), z poświęceniem przekazywał współczesną paideę mającą za fundament katolicki aksjologię i antropologię personalistyczną, lokującą istotę człowieczeństwa w osobowej godności i wynikających z godności właściwościach oraz powinnościach. Wskazywał sedno osobowego rozwoju „W realizacji” przekazywanych wychowankom wartości („realizacji”) prawdy, dobra, piękna ${ }^{111}$, spełnianiu siebie przez ich uczestnictwo $\mathrm{w}$ życiu indywidualnym, małżeńskim, rodzinnym i społecznym. Tak rozumiana aksjologiczna paideia jako ideał wychowania ks. J. Michalca łączy obdarzanie prawdą, dobrem, pięknem $\mathrm{z}$ istotą człowieczeństwa, $\mathrm{z}$ osobowo rozumianą odpowiedzialnością i wychowaniem do miłości - małżeństwa - rodziny ${ }^{112}$. Jednoczy bytowanie i wy-

106 Ostrowska, Aksjologia pedagogiczna - subdyscyplina, 11.

107 Olbrycht, Prawda, dobro, piękno, 35.

108 Alan Bullock, Hitler. Studium tyranii, przeł. Tadeusz Evert, wyd. 4 (Warszawa: Iskry 1997), 433.

109 Encyklika Evengelium vitae Ojca Świętego Jana Pawła II do biskupów, do kapłanów i diakonów, do zakonników i zakonnic, do katolików świeckich oraz do wszystkich ludzi dobrej woli o wartości i nienaruszalności życia ludzkiego, w Rzymie, u św. Piotra, dnia 25 marca 1995, w uroczystość Zwiastowania Pańskiego, w siedemnastym roku mego Pontyfikatu (Wydawnictwo Pallotinum 1995).

110 Krąpiec, Dzieła, Metafizyka, 5.

111 Olbrycht, Prawda, dobro, piękno, 35.

112 Wymienione kwestie po części inspirowane są filozoficzno-antropologiczną koncepcją współcześnie zinterpretowanej paidei, jako personalistycznego ideału wychowania autorstwa K. Olbrycht nawiązującego do personalizmu egzystencjalnego, szczególnie do stanowiska określanego również mianem personalizmu tomistyczno-fenomenologicznego (Olbrycht, Prawda, dobro, 
chowanie z człowieczeństwem, wartościami, jakimi są Bóg, wiara katolicka, naród, dom rodzinny, jego kultura ${ }^{113}$. Zatem współczesny ks. J. Michalcowi ideał wychowania stanowi człowiek jako osoba święta, wykształcona, religijna, świadomie i rozumnie kierująca swoim rozwojem do funkcjonowania w rzeczywistości przyrodzonej, a następnie nadprzyrodzonej - zbawczej.

Wbrew założeniom „rewolucji obyczajowej” (wspomniana rewolucja 1968 roku i dalsze lata), najpierw w domu rodzinnym ideał ten zapewnić powinien dziecku wychowanie i obecność rodziców (matki i ojca), ich autorytet, godziwą miłość, warunki utrzymania, wychowanie moralne, etyczne, estetyczne, intelektualne. Współdziałanie rodziców winno zmierzać do wychowania przez: codzienność, wartości, normy, zwyczaje, identyfikację z ojcem, matką, różnorodne procesy poznawcze, domową kulturę materialno-duchową i pedagogiczną, charakterystyczną niepowtarzalność wychowawcy, jego osobowość (Władysław Cichoń) i autorytet. Rodzina jako „modelowa” dla dziecka wspólnota zapewnić ma wdrażanie do: edukacji, świadomego wychowania aksjologicznego, transmisji i internalizacji kultury, wartości chrześcijańskich, wszechstronnego rozwoju osobowości, utwierdzania poczucia odpowiedzialności, tożsamości i wspólnoty rodowej. Wychowanie chrześcijańskie to $\mathrm{w}$ konsekwencji przygotowanie do realizacji prawdziwej, ciągle aktualnej miłości, małżeństwa i rodziny, uwzględniającej wychowanie seksualne, w tym wychowanie do czystości przedstawiającej dziecku sprawy cielesne w odpowiednim dla jego rozwoju czasie. W tym zakresie należy postępować z kulturą moralną polegającą na delikatnej dyscyplinie surowości, tzn. bez grzesznego, antywychowawczego prowokowania zmysłowości ${ }^{114}$, zwłaszcza wzrokowej ${ }^{115}$, na rzecz integralnej moralnie miłości jako daru Bożego. W razie rozpoznania w dziecku oznak Bożego powołania do kapłaństwa, stanu zakonnego, należy dołożyć wszelkiej troski i starań, „aby wychowywać do dziewictwa, jako najwyższej formy owego daru z siebie, który jest istotnym sensem płciowości ludzkiej”"116.

W przekonaniu ks. J. Michalca dzięki wartościom chrześcijańskim Kościół katolicki, katolicka myśl naukowa, parenetyczna i pedagogia, zintegrowane,

piękno, 35, 43). Zagadnienie personalizmu tomistyczno-fenomenologicznego K. Wojtyły zob.: Kowalczyk, Nurty personalizmu, 221.

113 „Przyjmuje się dość powszechnie, że rola rodziny w przekazywaniu wartości swemu potomstwu, norm i zwyczajów postępowania jest nadal pierwszoplanowa i najważniejsza. [...]. Od urodzenia, aż do śmierci jednostka jest pod wpływem tego, co myślą, co cenią, do czego dążą, w co wierzą, co uznają za najważniejsze, według jakich zasad postępują rodzice i inni członkowie rodziny”. Stanisław Kawula, Józefa Brągiel, Andrzej Janke, Pedagogika rodziny, Obszary i panorama problematyki, wyd. 3 (Toruń: Wydawnictwo Adam Marszałek 1998), 12.

114 Drogi miłości: miłość seksualna, 141.

115 „Za brak powściągliwości wzroku odpowiedzialna jest ciekawość, wykorzystująca bramy zmysłów, przez które obrazy wchodzą do świadomości i pamięci, by tam przebywać w sposób niczym nie skrępowany”. Wiesław Dawidowski, „Spectaculum - Deus ipse est”. Ethos 1-2 (2007): 80.

116 List do rodzin Ojca Świętego, 71. 
ponadczasowe wychowanie religijne, ma przygotować rodzinę do odpowiedzi na aksjologiczne przemiany współczesnego świata ${ }^{117}$ we współdziałaniu z Duchem Świętym, do zabierania głosu w sprawach cywilizacyjno-kulturowych, społeczno-politycznych, egzystencjalnych, wychowawczych, przypominania światu, kim jest człowiek, jaki jest jego cel, czym jest autorytet i solidarność Ewangelii, miłość - małżeństwo - rodzina. Twierdzi, że w wychowaniu należy zmierzać do wielkiej syntezy modlitwy indywidualnej i wspólnotowej, ustawicznej pracy nad sobą, refleksyjnej moralności, usuwania krzywd, zadawania śmierci, wywoływania wojen, na rzecz wdrażania chrześcijańskiego rozumienia życia i pokoju w małżeństwie, rodzinie, społeczeństwie i świecie ${ }^{118}$. Z mocą kapłańskiego autorytetu ostrzegał, iż cel, jakim jest wychowanie do miłości - małżeństwa - rodziny, wraz z rozwojem współczesnego „małego kościoła domowego”, stanowi również cel i przestrzeń najbardziej totalnej - ze wszystkich dotychczasowych - aksjologicznych konfrontacji dobra ze złem, która precyzyjnie zaplanowana, realizowana, także z pomocą islamu w Europie, „testuje” determinację współczesnego chrześcijaństwa, poddając próbie jego doktrynalną i społeczną trwałość, a przede wszystkim Dziesięć Przykazań. Zmierza do ukształtowania jednostki „totalnej”, zepsutej moralnie, pozbawionej godności i tożsamości, wyalienowanej ze wspólnoty ogólnoludzkiej, narodowej, małżeńskiej i rodzinnej. Ks. J. Michalec nie tylko ostrzegał, że konfrontacja ta ma charakter globalny we wszystkich obszarach cywilizacyjno-kulturowych, „idąc” ostatecznie przez małżeństwo i rodzinę. $\mathrm{Z}$ duszpastersko-wychowawczą troską wskazywał na wypaczanie ich istoty, funkcji, przez działające jawnie i z ukrycia światowe, instytucjonalne, „demoniczne siły” ${ }^{119}$, przeciwne kulturze, tj. „synonimowi wychowania” i wychowaniu jako „odpowiednikowi kultury”, w obu przypadkach będącymi immanentnymi środkami duchowo-materialnego rozwoju człowieka jako jej punktu centralnego. Otwarcie uświadamiał, że siły te są przeciwne kulturze katolickiej, mającej za przedmiot realizowanej misji największe przykazanie miłości, a wraz z nim: prawo do życia, zniesienie aborcji, nierozerwalne małżeństwo, trwałą rodzinę, do realizacji których istnieje niezbywalne prawo, a także obowiązek moralny.

Wielkim osiągnięciem misji ks. J. Michalca jest rozpoznanie, dostrzeżenie, nazwanie i zdiagnozowanie zagrożeń spowodowanych „cywilizacją śmierci”,

117 „Odzyskanie rodziny powinno się zacząć, według Dostojewskiego, od przywrócenia roli ojca, przywracania utraconych relacji pomiędzy ojcami i dziećmi. [...] Ważna [...] jest aktualizacja miłości, zrozumienia, cierpliwości, [...]. Rodzina, według Dostojewskiego, dana jest z niebios, jako najwyższa święta idea”. Anastazja N. Koszeczko, „Rodzina w egzystencjalnym paradygmacie Dziennika pisarza Fiodora M. Dostojewskiego", w: Wychowanie w rodzinie. Od starożytnej myśli filozoficznej do współczesnych rozwiązań legislacyjnych 1 (2013): 55.

118 Ryszard Małachowski, „Kroskulturowe aspekty wojny i walki w globalnej przestrzeni wychowania. Perspektywa historiozoficzna”, w: Edukacyjne przestrzenie. Wybrane problemy pedeutologii, opieki i wychowania w ujęciu komplementarnym, red. Robert Fudali (Zielona Góra: Oficyna Wydawnicza Uniwersytetu Zielonogórskiego 2010).

119 „Zmartwychwstanie wskazuje istotny porządek życia”, w: Michalec, Aby życie mieli, t. 1, 74. 
którym przeciwstawiła się katolicka pedagogia kontynuowana w XX/XXI wieku i jej głęboka potrzeba namysłu nad zagadnieniem wychowania do miłości małżeństwa - rodziny. Miało w tym udział jego kaznodziejskie nauczanie, zaangażowanie pronatalistyczne, dokonania przedstawicieli różnych środowisk naukowych, politycznych w Polsce i na świecie. W decydującej mierze dzięki kaznodziejskiemu nauczaniu i pedagogii nastąpiło prorodzinne odrodzenie misyjne laikatu u końca drugiej dekady XXI wieku, przybierające na sile w wielu krajach świata i Europie, także w Europie Środkowo-Wschodniej, np. w Macedonii, Czarnogórze, Chorwacji, na Węgrzech. Obecnie w Polsce stopień udziału każdego aktu prawnego w procesie budowania trwałej „polityki prorodzinnej” (nie mylić $\mathrm{z}$ „polityką socjalną") ma pozytywne nastawienia do: ideału artykułu 18 Konstytucji RP, trwałości zasady „prolife”, małżeństwa i rodziny, prorodzinnych programów edukacyjnych (naturalnego wzoru ojcostwa, macierzyństwa, konsolidujących sposobów rozwiązywania kryzysów małżeńskich - egzemplifikowanych w lekturach szkolnych), ograniczenia liczby rozwodów niszczących niemal całkowicie strukturę społeczną, emigracji ludzi młodych ${ }^{120}$. Proces ten powstrzymać i odwrócić może kulturowo-aksjologiczna w tym pedagogiczna, edukacyjno-wychowawczo- biografistyczna oraz materialna polityka prorodzinna, wsparta integralnie przez kompetentne instytucje państwa i nadal aktywnego Kościoła katolickiego.

Streszczeni e: Przedstawiony artykuł dotyczy aksjologicznego wychowania chrześcijańskiego w kaznodziejstwie i pedagogii ks. Juliana Michalca, urodzonego na Kresach PołudniowoWschodnich II Rzeczypospolitej Polskiej w 1922 roku, zmarłego w 1988 roku. Nauczanie tegoż duszpasterza-wychowawcy skierowane było głównie do młodzieży akademickiej archidiecezji przemyskiej i wrocławskiej w latach 1962-1988, w okresie Polskiej Rzeczypospolitej Ludowej. Realizowane w warunkach totalitarnych, m.in. w zakresie wychowania do miłości małżeństwa - rodziny (kontekst aksjologiczny: religijno-wychowawczy, wybrane aspekty filozoficzno-teologiczne, antropologiczne, ontologiczne, aksjologiczno-pedagogiczne, psychologiczne i socjologiczne: religii, kulturoznawstwa, historii, zwłaszcza nauk o rodzinie), uchroniło młodzież polską i jej rodziny przed dechrystianizacją.

Słowa kluczowe: biografia, wartość, aksjologia, kazanie, homilia, miłość, małżeństwo, rodzina, duszpasterz - wychowawca, duszpasterstwo akademickie, chrześcijaństwo

\section{Bibliografia}

„Droga miłości [83]”. W: Posynodalna adhortacja apostolska Ecclesia in Europa Ojca Świętego Jana Pawła II. Do biskupów, do kapłanów i diakonów, do zakonników i zakonnic oraz do wszystkich wiernych o Jezusie Chrystusie, który żyje w Kościele, jako źródło nadziei dla Europy. Wrocław: Wydawnictwo Wrocławskiej Księgarni Archidiecezjalnej TUM, 2003.

120 Paulina Gajkowska, „Prawo bliżej rodziny”. Nasz Dziennik 249 (2017): 4. 
„Drogi miłości: miłość seksualna i erotyczna”. W: Michalec, Julian. Aby życie mieli. Wybór kazań, T. 2, wyb. i red. Maria Lubieniecka. Kraków: Wydawnictwo OO. Franciszkanów Bratni Zew, 2002.

„Łączność z Panem Bogiem przez intencję - stan świadomości”. W: Michalec, Julian. Aby życie mieli. Wybór kazań, t. 2, wyb. i red. Maria Lubieniecka. Kraków: Wydawnictwo OO. Franciszkanów Bratni Zew, 2002.

„Miłość erotyczna, miłość upodobania”. W: Michalec, Julian. Aby życie mieli. Wybór kazań, t. 2, wyb. i red. Maria Lubieniecka. Kraków: Wydawnictwo OO. Franciszkanów Bratni Zew, 2002.

„Nadrzędny cel małżeństwa i rodziny”. W: Michalec, Julian. Aby życie mieli. Wybór kazań, t. 2, wyb. i red. Maria Lubieniecka. Kraków: Wydawnictwo OO. Franciszkanów Bratni Zew, 2002.

„Największa jest miłość”. W: Zienkiewicz, Aleksander. Kazania i homilie na różne okazje, red. Jadwiga Wartalska. Kraków: Wydawnictwo OO. Franciszkanów Bratni Zew, 2006.

„Rodzina jako szkoła miłości”. W: Parzyszek, Magdalena. Rodzina w nauczaniu kardynała Stefana Wyszyńskiego. Aspekt pedagogiczny. Lublin: Wydawnictwo KUL, 2012.

„Słowo wstępne ks. kardynała Karola Wojtyły arcybiskupa metropolity krakowskiego”. W: Bednarski, Feliks W. Wychowanie młodzieży dorastajacej. Rzym: Papieski Instytut Studiów Kościelnych, 1976.

„Wartości”. W: Kowalczyk, Stanisław. Z refleksji nad człowiekiem. Człowiek - społeczność - wartość, 215-224. Lublin: Towarzystwo Naukowe Katolickiego Uniwersytetu Lubelskiego, 1995.

„Zdecydujmy się na miłość". W: Posynodalna adhortacja apostolska Ecclesia in Europa Ojca Świętego Jana Pawła II. Do biskupów, do kapłanów i diakonów, do zakonników i zakonnic oraz do wszystkich wiernych o Jezusie Chrystusie, który żyje w Kościele, jako źródło nadziei dla Europy. Wrocław: Wydawnictwo Wrocławskiej Księgarni Archidiecezjalnej TUM, 2003.

Adhortacja apostolska Familiaris consortio Ojca Świętego Jana Pawła II do biskupów, kapłanów i wiernych całego Kościoła katolickiego, O zadaniach rodziny chrześcijańskiej w świecie wspótczesnym. Rzym, 22 listopada 1981 r. Wrocław: Wydawnictwo Wrocławskiej Księgarni Archidiecezjalnej TUM, 1981.

Balczerzak-Paradowska, Bożenna. Rodzina i polityka rodzinna na przełomie wieków: przemiany, zagrożenia, potrzeba działań. Warszawa: Instytut Pracy i Spraw Socjalnych, 2004.

Bednarski, Feliks W. Wychowanie młodzieży dorastającej. Rzym: Papieski Instytut Studiów Kościelnych, 1976.

Biograficzne badania nad twórczością. Teoria i empiria, red. Monika Modrzejewska-Świegulska. Łódź: Wydawnictwo Uniwersytetu Łódzkiego, 2016.

Bober, Sabina. Walka o dusze dzieci i młodzieży w pierwszym dwudziestoleciu Polski Ludowej. Lublin: Wydawnictwo Katolickiego Uniwersytetu Lubelskiego, 2011.

Braun-Gałkowska, Maria. Psychologiczna analiza systemów rodzinnych osób zadowolonych i niezadowolonych $z$ małżeństwa. Lublin: Towarzystwo Naukowe KUL, 1992.

Bullock, Alan. Hitler, Studium tyranii, przeł. Tadeusz Evert. Warszawa: Iskry, 1997.

Chałasiński, Józef. Młode pokolenie wsi Polski Ludowej. Awans pokolenia. Pamiętniki i Studia, t. 1. Warszawa: Ludowa Spółdzielnia Wydawnicza, 1964.

Cyran, Grzegorz. „Doświadczenie Judasza w pedagogii wiary”. W: Język doświadczenia religijnego, red. Grzegorz Cyran, Elżbieta Skorupska-Raczyńska, t. 3. Szczecin: Wydawnictwo Volumina pl Daniel Krzanowski, 2010.

Dawidowski, Wiesław. „Spectaculum - Deus ipse est”. Ethos 1-2 (2007).

Dives in misericordia, Encyklika Ojca Świętego Jana Pawła II o Bożym miłosierdziu. Warszawa: Wydawnictwo Ośrodka Dokumentacji i Studiów Społecznych, 1981. 
Encyklika Deus caritas est Ojca Świętego Benedykta XVI. Do biskupów, prezbiterów i diakonów, Do osób konsekrowanych i wszystkich wiernych świeckich o miłości chrześcijańskiej. Kraków: Wydawnictwo M, 2006.

Encyklika Evengelium vitae Ojca Świętego Jana Pawła II do biskupów, do kapłanów i diakonów, do zakonników i zakonnic, do katolików świeckich oraz do wszystkich ludzi dobrej woli o wartości i nienaruszalności życia ludzkiego. W Rzymie, u św. Piotra, dnia 25 marca 1995, w uroczystość Zwiastowania Pańskiego, w siedemnastym roku mego Pontyfikatu. Wydawnictwo Pallotinum, 1995.

Encyklika Piusa XI O chrześcijańskim wychowaniu młodzieży, Divini illius Magistri. Warszawa: Wydawnictwo Te Deum, 1999.

Encyklopedia aksjologii pedagogicznej, red. Krystyna Chałas, Adam Maj. Radom: Polskie Wydawnictwo Encyklopedyczne Polwen, 2016.

Encyklopedia katolicka, red. Jan Walkusz, Lublin 1993.

Encyklopedia katolicka, red. Ludomir Bieńkowski, Feliks Gryglewicz, Romuald Łukaszyk, t. 4. Lublin: Towarzystwo Naukowe KUL, 1985.

Evdokimov, Paul. Gogol i Dostojewski czyli zstapienie do otchłani, przeł. Adriana Kunka. Bydgoszcz: Wydawnictwo Homini, 2002.

Fras, Zbigniew. „Kresy i pogranicza”. W: Kresy i pogranicza. Historia, kultura, obyczaje, red. Zbigniew Fras, Andrzej Staniszewski. Olsztyn: Wydawnictwo Wyższej Szkoły Pedagogicznej, 1995.

Gajkowska, Paulina. „Prawo bliżej rodziny”. Nasz Dziennik 249 (2017).

Gravissimum educationis. Deklaracja o wychowaniu chrześcijańskim (Sobór Watykański II). Przedruk za: Sobór Watykański II, Konstytucje, dekrety, deklaracje. Poznań: Wydawnictwo Oficyna Współczesna, 2001.

Grochocińska, Rita. Psychospołeczna sytuacja dzieci w rodzinach rozbitych. Gdańsk: Wydawnictwo Uniwersytetu Gdańskiego, 1990.

Hadaczek, Bolesław. Postać pedagoga w literaturze polskiej. Warszawa - Poznań: Państwowe Wydawnictwo Naukowe, 1977.

Hejnicka-Bezwińska, Teresa. „Problemy aksjologiczności pedagogii”. W: Pedagogika ogólna. Problemy aksjologiczne, red. Teresa Kukołowicz, Marian Nowak. Lublin: Redakcja Wydawnictw KUL 1997.

Ilgiewicz, Henryka. „Litewska kontestacja pojęcia «Kresy Wschodnie»”. W: Europa nie prowincjonalna. Przemiany na ziemiach wschodnich dawnej Rzeczypospolitej (Białoruś, Litwa, Łotwa, Ukraina, wschodnie pogranicze III Rzeczypospolitej Polskiej) w latach 1772-1999, red. Krzysztof Jasiewicz. Warszawa: Oficyna Wydawnicza Rytm, 1999.

Ingarden, Roman. Przeżycie, dzieło, wartość. Kraków: Wydawnictwo Literackie, 1966.

Jagielska, Dominika, Janina Kostkiewicz. Pedagogika humanizmu społecznego Andrzeja Niesiołowskiego. Kraków: Wydawnictwo Uniwersytetu Jagiellońskiego, 2015.

Kawula, Stanisław, Józefa Brągiel, Anadrzej Janke, Pedagogika rodziny. Obszary i panorama problematyki. Toruń: Wydawnictwo Adam Marszałek, 1998.

Kobieta wychowawczynią do życia w pokoju, Orędzie Jego Świątobliwości papieża Jana Pawła II na XXVIII Światowy Dzień Pokoju, wygłoszone 1 stycznia 1995 roku.

Kornacka-Skwara, Elżbieta. Psychologiczna analiza systemów rodzinnych mężczyzn bezrobotnych. Częstochowa: Wydawnictwo Wyższej Szkoły Pedagogicznej, 2004.

Koszeczko, Anastazja N. „Rodzina w egzystencjalnym paradygmacie Dziennika pisarza Fiodora M. Dostojewskiego". W: Wychowanie w Rodzinie. Od starożytnej myśli filozoficznej do współczesnych rozwiązań legislacyjnych 1 (2013). 
Kowalczyk, Stanisław. Człowiek w poszukiwaniu wartości. Elementy aksjologii personalistycznej. Lublin: Wydawnictwo KUL, 2006.

Kowalczyk, Stanisław. Nurty personalizmu. Od Augustyna do Wojtyły. Lublin: Wydawnictwo KUL, 2010.

Krąpiec, Mieczysław A. Dzieła. Metafizyka. Zarys teorii bytu. Lublin: Redakcja Wydawnictw KUL, 1995.

Kryzys współczesnej rodziny a wychowanie. W: Bednarski, Feliks W. Wychowanie młodzieży dorastającej. Rzym: Papieski Instytut Studiów Kościelnych, 1976.

Kupisiewicz, Czesław, Małgorzata Kupisiewicz, Poczet wybitnych nauczycieli. Pułtusk: Wydawnictwo Akademia Humanistyczna im. A. Gieysztora w Pułtusku, cz. I, 2006.

Kupisiewicz, Czesław, Małgorzata Kupisiewicz, Poczet wybitnych nauczycieli. Pułtusk: Wydawnictwo Akademia Humanistyczna im. A. Gieysztora w Pułtusku, cz. II, 2007.

List do rodzin Ojca Świętego Jana Pawła II, Rok Rodziny 1994, reprint. Wrocław: Libreria Editrice Vaticana, Wydawnictwo Wrocławskiej Księgarni Archidiecezjalnej, 1994.

Maliński, Mieczysław. Zanim powiesz kocham. Szczecin: Wydawnictwo Ottonianum, 1990.

Małachowski, Ryszard. „Kroskulturowe aspekty wojny i walki w globalnej przestrzeni wychowania. Perspektywa historiozoficzna”. W: Edukacyjne przestrzenie. Wybrane problemy pedeutologii, opieki i wychowania w ujęciu komplementarnym, red. Robert Fudali. Zielona Góra: Oficyna Wydawnicza Uniwersytetu Zielonogórskiego, 2010.

Małachowski, Ryszard. „Nauczanie duszpastersko-wychowawcze w biografii pedagogicznej oraz kazaniach księdza Juliana Michalca (XX wiek)”. Scientific Bulletin of Chełm, Section of Pedagogy 1 (2017).

Małachowski, Ryszard. Wychowanie do miłości, małżeństwa i rodziny chrześcijańskiej, 448-492. W: tenże, Działalność wychowawcza księdza Aleksandra Zienkiewicza na Kresach Wschodnich Rzeczypospolitej i Dolnym Śląsku. Zielona Góra: Oficyna Wydawnicza Uniwersytetu Zielonogórskiego, 2013.

Małecka, E.M. [Katolicka Agencja Informacyjna]. „Kuria Rzymska, Kardynał Carlo Caffarra nie żyje”. Nasz Dziennik 207 (2017): 17.

Mazur, Piotr. Podstawy pedagogiki pastoralnej. Kraków: Wydawnictwo Apostolstwa Modlitwy, 2011.

Michalec, Julian. Aby życie mieli. Wybór kazań, t. 1, wyb. i red. Maria Lubieniecka. Kraków: Wydawnictwo OO. Franciszkanów Bratni Zew, 2001.

Michalec, Julian. Aby życie mieli. Wybór kazań, t. 2, wyb. i red. Maria Lubieniecka. Kraków: Wydawnictwo OO. Franciszkanów Bratni Zew, 2002.

Miodek, Jan. „Ksiądz Julian Michalec”. W: Michalec, Julian. Aby życie mieli. Wybór kazań, t. 1, wyb. i red. Maria Lubieniecka. Kraków: Wydawnictwo OO. Franciszkanów Bratni Zew, 2001.

Misztal, Maria. Problematyka wartości w socjologii. Warszawa: Państwowe Wydawnictwo Naukowe, 1980.

Moszumański, Krzysztof. Ks. Julian Michalec (1922-1988). Człowiek i dzieło. Świdnica: Świdnicka Kuria Biskupia, 2005.

Możdżeń, Stefan I. Fałszywe drogi wychowania. Sandomierz: Wydawnictwo Diecezjalne, 2013.

Niewęgłowski, Jan. Wychowawczo-społeczna działalność salezjanów w Polsce w latach 18981989. Warszawa: Towarzystwo Naukowe Franciszka Salezego, 2011.

Olbrycht, Katarzyna. Prawda, dobro, piękno w wychowaniu człowieka jako osoby. Katowice: Wydawnictwo Uniwersytetu Śląskiego, 2000.

Ostrowska, Urszula. „Aksjologia pedagogiczna - subdyscyplina naukowa pedagogiki (in statu nascendi)”. Roczniki Pedagogiczne 9 (2017). 
Pedagogie katolickich zgromadzeń zakonnych. Historia i współczesność, t. 1, red. Janina Kostkiewicz. Kraków: Oficyna Wydawnicza „Impuls” 2012.

Pismo Święte Starego i Nowego Testamentu, w przekładzie z języków oryginalnych, Biblia Tysiąclecia, red. Augustyn Jankowski, Lech Stachowiak, Kazimierz Romaniuk. Poznań - Warszawa: Wydawnictwo Pallotinum, 1984.

Rodzina polska u progu XXI wieku. I sympozjum naukowe [...] w Łowiczu, 20-21 maja 1996 roku, red. Henryk Cudak. Łowicz: Mazowiecka Wyższa Szkoła Humanistyczna, 1996.

Sapia-Drewniak, Eleonora. Stefania Mazurek. Biografia pedagogiczna. Opole: Wydawnictwo Uniwersytetu Opolskiego, 2011.

Schneider, Athanasius. „Proroczy głos. Czterech kardynałów świętego Kościoła rzymskokatolickiego", przeł. z ang. Jadwiga Stachurska. Nasz Dziennik 285 (2016).

Sochoń, Jan. „Teatr jako miejsce teologiczne. Wizja Tadeusza Kantora”. Ethos 1-2 (2007).

Styczeń, Tadeusz. Urodziłeś się by kochać. Lublin: Towarzystwo Naukowe KUL, 1993.

Sztaba, Mariusz. „Rzecz o fundamentalnym wyborze pomiędzy realizmem a idealizmem w tworzeniu adekwatnej koncepcji wychowania”. Roczniki Pedagogiczne 1 (2015).

Szulakiewicz, Władysława. „Andragogiki portret zbiorowy w kontekście dyskusji o sensie badań biograficznych”. Rocznik Andragogiczny 20 (2013).

Szymaniak, Jadwiga. „Metoda biograficzna w pedagogice”. Studia Gdańskie 10 (2013).

Świętymi bądźcie. Orędzia Ojca Świętego Jana Pawła II na Światowe Dni Młodzieży, red. Henryk Tomasik. Częstochowa: Biblioteka „Niedzieli”, t. 137, 2002.

Tatarkiewicz, Władysław. Historia filozofii, Filozofia starożytna i średniowieczna, t. 1. Warszawa: Państwowe Wydawnictwo Naukowe, 1981.

Theiss, Wiesław. Troska i nadzieja: działalność społeczno-wychowawcza ks. Henryka Szumana na Pomorzu w latach 1908-1939. Toruń: Wydawnictwo Adam Marszałek, 2012.

Thomas, William L., Florian Znaniecki. Chłop polski w Europie i Ameryce, przeł. Anna Bartkowicz. Warszawa: Ludowa Spółdzielnia Wydawnicza, 1976.

Trobisch, Walter. Miłości trzeba się uczyć. Częstochowa: Wydawnictwo Misjonarzy Krwi Chrystusa - Pomoc, 1999.

Wałęga, Agnieszka. „Biografistyka w naukach o wychowaniu na marginesie pracy Stefania Mazurek. Biografia pedagogiczna". Pedagogika 38 (2012).

Wojdon, Joanna. Propaganda polityczna w podręcznikach dla szkót podstawowych Polski Ludowej (1944-1989). Toruń: Wydawnictwo Adam Marszałek, 2001.

Wojtyła, Karol. Miłość i odpowiedzialność. Lublin: Towarzystwo Naukowe KUL, 1986.

Wołoszyn, Stefan. „Kategoria «powinności» jako podstawowa aksjologiczna kategoria pedagogiki jak ją rozumieć?”. W: Pedagogika ogólna. Problemy aksjologiczne, red. Teresa Kukołowicz, Marian Nowak (Lublin: Redakcja Wydawnictw KUL, 1997).

Woroniecki, Jacek. „Program pedagogiki katolickiej”. W: Pedagogika katolicka. Zagadnienia wybrane, red. Alina Rynio. Stalowa Wola: Oficyna Wydawnicza Fundacji w Stalowej Woli, 1999.

Wychowanie w rodzinie od starożytności po wiek XX, red. Juliusz Jundziłł, Materiały z Konferencji Naukowej Katedry Historii Wychowania. Bydgoszcz: Wydawnictwo Uczelniane Wyższej Szkoły Pedagogicznej, 1994.

Ziemiński, Ireneusz. „Sumienie nauki, O roli mistrza w kształceniu uniwersyteckim”. Ethos 1-2 (2009).

Zienkiewicz, Aleksander. Miłości trzeba się uczyć. Rady dla młodych. Wrocław: Oficyna Współczesna, 1994. 
Zienkiewicz, Aleksander. Wzrastać w światłości. Stawać się chrześcijaninem. Stawać się księdzem. Zbiór kazań, red. Jadwiga Wartalska. Kraków: Wydawnictwo OO. Franciszkanów Bratni Zew, 2000.

Zienkiewicz, Aleksander. Z problematyki wychowujacego nauczania wiary i moralności - argumentacja i motywacja. Uwagi wstepne - fundamentalne. Opracowanie z dnia 28 maja 1981 r., 9 [archiwum prywatne Ryszarda Małachowskiego]. 